\title{
Ceramics and Society in Mahan and Paekche: A Comparison of Pottery Geochemistry and Craft Production Patterns at the Sites of P'ungnap T'osŏng and Kwangju Palsan
}

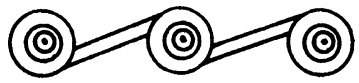 \\ Rory Walsh, Gyoung-Ah LeE, and Young-Cheol LeE
}

\begin{abstract}
The archaeological cultures of the Korean peninsula provide numerous case studies of the formation, structure, and function of ancient complex societies and states. In southwestern Korea, the Mahan (ca. 50 B.C.E.-C.E. 475) occupied a large region marked by similarities in material culture, but decentralized politically. The Paekche kingdom (ca. C.E. 250-660) had its origins as a Mahan polity in the Han River valley, later centralizing its authority and expanding its territory. This article discusses two sites: the Paekche capital of P'ungnap T'osŏng in modern Seoul and a large Mahan town recently excavated in Chŏlla Province known as Kwangju Palsan. The political economy and social structure of each site is investigated using ceramic remains, artifacts that played a large role in daily life across classes and in the elaboration of elite culture. With highresolution chemical data from Instrumental Neutron Activation Analysis (INAA) on potsherds, specific production signatures can be identified for each site. This allows comparison of the proportion of locally produced and imported pottery at each site and even reveals when P'ungnap T'osŏng and Kwangju Palsan exchanged ceramic goods. These patterns reveal similarities and differences in Mahan and Paekche political economies, ultimately illuminating the Mahan roots of Paekche social organization. KeYwOrds: Korea, complex societies, Instrumental Neutron Activation Analysis, craft production.
\end{abstract}

\section{INTRODUCTION}

The period immediately preceding the Three Kingdoms in the southern Korean peninsula goes by various names: the Proto-Three Kingdoms, a straightforward if teleological label; the Samhan 三韓, a historically-based name that effectively excludes the northern half of the peninsula; and the Iron Age, an appeal to the generality of the three-age system. This lack of agreement in nomenclature reflects a greater lack of clarity on the Korean state formation process itself. In the southwest, where histories

Rory Walsh is a Korea Foundation Postdoctoral Fellow at the University of Michigan. Gyoung-Ah Lee is an Associate Professor at the University of Oregon. Young-Cheol Lee is Director of the Daehan Institute of Cultural Properties 


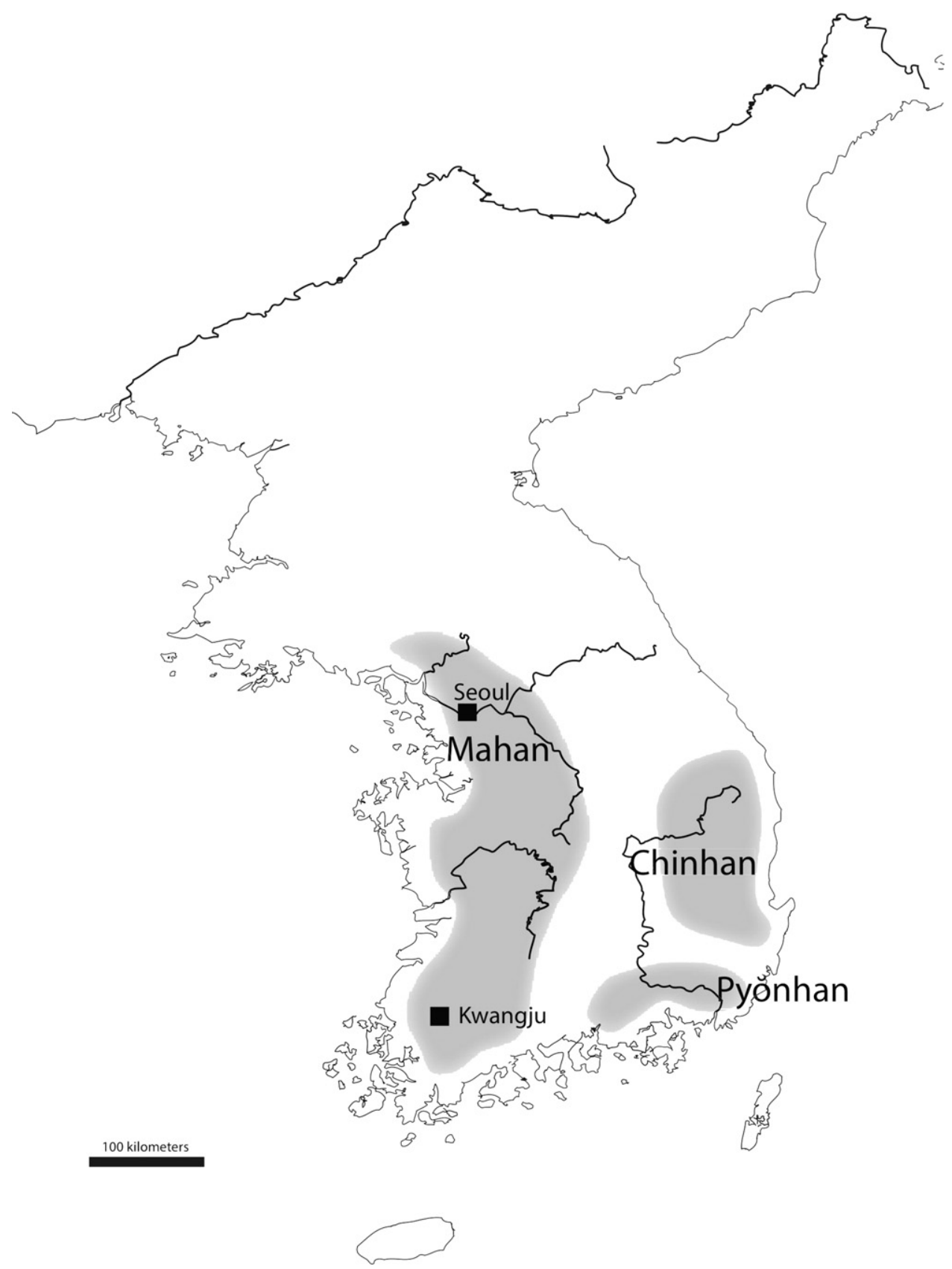

Fig. 1. Map showing locations of Seoul and Kwangju, where the sites of P'ungnap T'osŏng and Palsan, respectively, have been excavated. Gray shading indicates possible geographical extent of three Han societies: Mahan, Chinhan, Pyonhan (adapted from Byington 2009). 
present stories of centuries-old royal lineages and swift conquests, the archaeological record of the first few centuries C.E. clearly demonstrates that the Paekche 百濟 (RR: Baekje) kingdom (ca. C.E. 300-660) shared a great deal of material culture with its predecessor. This earlier society is identified in the archaeological and historical tradition as Mahan 馬韓, one of three supposed 'Han' groups described in the Sanguozhi 三國志 known collectively as the Samhan (Byington 2009) (Fig. 1). Whether the Mahan was in fact one society or several has been increasingly called into question (Kwŏn Oyŏng 2015; Davey and Lee this issue), as has the geographical extent and internal variation of its culture. In the midst of this reexamination of Mahan and in hopes of contributing to it, this article uses the label Mahan heuristically and provisionally to refer to the people who predated Paekche and also coexisted alongside the kingdom for the entirely of the Hansong 漢城 (RR: Hanseong) period (ca. C.E. 300-475). The effort to better define Mahan cultures and conceptualize Paekche state formation requires a thorough evaluation of the social, political, and economic ties between Mahan and Paekche communities and questioning how the people of these societies constructed their identities as separate from each other.

Excavations in Chŏlla (RR: Jeolla) Province over the past decade have demonstrated that the Mahan cultures that developed there before the start of the Three Kingdoms period continued to thrive through the fourth and fifth centuries (Im 2014; Kim S. 2014; Pak 2015; Sŏ 2014; Yang 2013; Yi N. 2013). Even after the Paekche capital was moved south for the first time in C.E. 475, Mahan-style settlements, burials, and pottery persisted, with some incorporation of Paekche styles. This study looks to address the relationship between Mahan and Paekche culture by examining ceramic remains, common everyday objects that were used by people of all social classes in both societies. Geochemical analyses and provenance determination of ceramics allow for detailed investigation of the internal political economies and intersocietal exchange relationships of two sites, one Mahan and one Paekche. Using the analytical precision allowed by Instrumental Neutron Activation Analysis (INAA), this study explores similarities in patterns of ceramic production and consumption that reveal a fundamental connection between the strategies deployed at these sites, even as these two systems supported political leadership at very different scales.

\section{BACKGROUND}

This study compares two sites: P'ungnap T'osŏng (RR: Pungnap-toseong), the fortified Paekche city that has been excavated since the 1990s, and Kwangju Palsan (RR: Gwangju Balsan), a recently discovered large settlement site in Chŏlla Province for which an excavation report is still to be published. While radiocarbon dates are not yet available for Palsan, relative dates on pottery suggest these sites were roughly contemporaneous, with both sites likely occupied throughout the fourth century C.E., P'ungnap T'osŏng abandoned in C.E. 475, and Palsan sometime in the sixth century. The pottery remains at Palsan lack the elaborate forms associated with the Paekche kingdom and which would be expected at a Paekche site of this size. Palsan therefore falls into the general category of 'Mahan'.

The identity and nature of Mahan culture is unclear given the current state of historical and archaeological evidence. The Sanguozhi account of the Mahan describes a society of allied polities based on an infrastructure of towns and territories (Best 2006). Such an organizational system has been difficult to corroborate archaeologically, 
as relatively few Mahan settlements have so far been recovered. Mahan culture has primarily been recognized through its burials, which in the early period typically consist of a coffin, generally two large jars made to interlock at the rims or sometimes a wooden casket, overlaid with a mound of earth or stone (Yi N. 2013). Members of the same clan were buried in proximity, and sometimes even together, as demonstrated by DNA testing on rare surviving human remains (Im 2014). This mortuary system existed with very little variability for the first three centuries C.E., but began to incorporate new forms and styles after approximately C.E. 300, leading to a highly varied burial system among the Mahan cultures located in modern Chŏlla Province (Kwŏn 2015). Paekche tombs from the Hansŏng period cemetery at Sŏkch'on-dong (Revised Romanization: Seokchon-dong) were also remarkably variable, mimicking Koguryŏ 高句麗 (RR: Goguryeo) tombs as well as the domed Silla style and other forms, but built with techniques not common in the other regions (Kim W. et al. 1989; Seoul 1975; Yi S. et al. 2013). More distinctly Paekche style monumental tombs such as that of King Muryŏng (r. 501-523) appear during the Ungjin (C.E. 476-538) and Sabi (C.E. 538-660) periods, when mounded Mahan tombs in the Youngsan (RR: Yeongsan) River region began incorporating the keyhole shape that typified tombs of the Kofun period in Japan. Lee (2014) suggests this may have been an expression of the local Mahan elites' connection to contemporaneous Japanese societies, one meant to reinforce their political and cultural distinction from southward-advancing Paekche while reminding the neighboring kingdom of their own prowess in overseas trade.

More information on the relationship of Mahan and Paekche in the fourth through sixth centuries is becoming available as the number of excavated settlements increases. In Chŏlla Province, known as Korea's "rice bowl," the relatively low modern population, coupled with a recent rise in development projects, has allowed for the discovery of over 150 settlements so far (Kim S. 2014). While further excavation, analysis, and dating are required to fully understand the settlement patterning of Mahan sites, Kim Sŭngok (2014) has compiled existing data for a provisional classification. The vast majority of sites contain between one and one hundred houses, which Kim groups into small (1-24 houses), medium (25-69), and large (more than 70) settlements. A few extra-large settlements $(1000+$ houses) appear later in the local sequence. Larger settlements in Kim's study tend to contain smaller houses, and may include an internal division between large and small houses. Sites of all sizes have above-ground granary structures that are larger in correlation with settlement size. Kilns within settlements tend to occur in the largest and smallest sites. In large sites, these kilns are assumed to have produced pottery for intra-site use, whereas kilns in very small settlements of two to five houses may have been used by more specialized producers.

Mahan ceramics are largely utilitarian in nature, with forms including multipurpose short-necked jars, deep bowls, horn-handled steamers, and boiling pots (Sŏ 2014). The basic paddle-and-anvil construction of Mahan pottery was carried forward from earlier traditions, but the central Mahan region adopted wheel finishing earlier than the southern Samhan groups, as early as the second century C.E. (Yi S. 2013). A frequent stylistic feature of pots from this region is the use of a decorated paddle to finish the clay surface, creating marks known as t'analmun 打捺文 (RR: tanalmun). Two distinct types of t'analmun appear, depending on whether impressions were made in the clay with a cord-wrapped paddle or from a grid design carved into the paddle (Tsuchida 2013). The same types of t'analmun decorated vessels used in daily life are found as burial offerings, and the ceramics themselves do not appear to have been used 
to mark social status either by quality or quantity (Choi 2008). In the fourth and fifth centuries, Mahan pottery incorporated Paekche forms such as pedestal bowls with lids, tripod vessels, and bottles, but in the Yŏngsan River basin, a core Mahan region, these were made with local construction and firing techniques (Sŏ 2014).

Listed in the Sanguozhi as one of over 50 Mahan polities, Paekche came to power as a separate political entity in the late third or early fourth century C.E. (Kwŏn 2011). Perhaps the most striking, and certainly the largest, difference in material culture introduced by Paekche was the construction of earthen-walled fortresses called t'osóng 土城 (RR: toseong). The earliest of these appears to have been P'ungnap T'osŏng on the Han River's southern bank, where large-scale excavations began in 1997 (Kwŏn 2008). The compound was enclosed by earthen walls constructed in the late third century, estimated to have been 43 meters thick, 11 meters tall, and over 3.5 kilometers in circumference. This would have required control over a large labor force, and the organization of the site suggests an extensive central area for the conduct of elite rituals. Several large pits have been recovered in this area with the remains of thousands of pottery vessels, sacrificial cows and horses, small figurines, mica, apricot pits, and other signifiers of elite behavior.

Compared with contemporaneous sites in the northern Paekche region, houses at P'ungnap T'osŏng contain high levels of both storing and serving vessels, and only moderate numbers of cooking vessels (Kim M. et al. 2016). Several large storage jars found in both houses and refuse pits in the central Kyŏngdang (RR: Gyeongdang) area of the site are glazed stoneware of Chinese manufacture (Hansŏng and Hansin 2011, 2015; Kim M. et al. 2016). The majority, however, are Paekche-produced jars, bowls, lidded vessels, and tripod dishes. Two styles of Proto-Three Kingdoms pottery continued into the Paekche period: gray yŏnjil 軟質 (soft-fired earthenware [RR: yeonjil]) and reddishbrown yŏnjil. The first evidence for local Korean production with firing temperatures above $1000{ }^{\circ} \mathrm{C}$ come from the Hansŏng Paekche period, with bluish-gray kyŏngjil 硬質 (stoneware [RR: gyeongjill) and black mayón 磨研 (RR: mayeon) or 'burnished' pottery appearing in P'ungnap T'osŏng and other sites. The development of blackware began in Mahan cultures (Nam 2013), but its popularity among Paekche elites was likely influenced by Chinese porcelain traditions, as some designs appear similar to Yue 越 and Western Jin 西晉 styles (Choi 2008).

Footed bowls, short neck jars, and broad-shouldered jars are common forms of blackware that do not appear to have Mahan roots (Sŏ 2014). This new style of pottery, often called 'Paekche style', has been conceptualized as a prestige ware owing to its distinctive shapes, and, in the case of blackware, attractive sheen. Paekche style pots begin to appear around the completion of construction of P'ungnap T'osŏng's walls, and the vessels appear mostly to be related to food practice, which Yi Sŏngju (2015) attributes to the elaboration of elite culinary culture. For decades, the working assumption was that Paekche-style wares would have been distributed throughout the kingdom from the Paekche core (Nam 2013). This interpretation followed from the Samguk sagi's 三國史記 narrative of state formation, which not only conceived of Paekche as something separate from Mahan and with leaders foreign to the area, but also told of a sudden and thorough expansion of Paekche territorial control using primarily military means. This model of statehood supposes a powerful central authority, echoing that of Imperial China, elevated above the rest of the population to such an extent that even the production of certain kinds of pottery would have been its exclusive purview. In contrast, Cho Daeyoun (2006) demonstrated that the black 
pottery in question was in fact produced in various places throughout the Paekche region, using techniques modified from local traditions. The production locations for blackware were, however, fewer in number than those for plainer styles. Nam Sangwŏn (2013) points out that not only did various producers in the Mahan region produce black or dark gray pottery predating Paekche blackware, but that when Paekche-style black jars were both imported and copied locally later in the sequence, they would have had different meanings outside of a central Paekche setting. This is borne out in the types of sites from which these jars are recovered. In Paekche core areas, blackware jars have been found in storage pits, houses, road works, and burials, but in Mahan cultural sites they are common only in burials. Some allowance must be made for the greater representations of burials in Mahan archaeological remains, but clearly these socially valuable items tell us less about Paekche's political expansion than the complex relationship between various reaches of Mahan and Paekche. While these studies focused on blackware jars, all categories of ceramics in Mahan and Paekche have the potential to yield such insights.

\section{CRAFT PRODUCTION AND SOCIAL IDENTITY}

The production of craft goods is a crucial economic activity in a complex society, but the behaviors involved in craft production also express, influence, and reify the social order in which craftspeople operate. Elites often invoke connections with remote entities both mundane and divine to justify their privileged position in this order, which are materialized in goods traded in from exotic locations as well as city walls, roads, ritual objects, personal adornments, and other locally produced goods (Helms 1993). Though made by non-elites, such objects represent the efforts of elites to bring the immediate world into accordance with the cosmic order to which they have particular access. Materializing elite connections in this way serves to institutionalize them, turning ideological authority into concrete control over resources and their distribution (DeMarrais et al. 1996; Vaughn 2006). Recent work by a number of scholars has re-examined these processes by shifting the focus for behavioral explanation to non-elites, with cooperation emerging as a crucial component of increasing social complexity (Blanton and Fargher 2008, 2016; Carballo and Feinman 2016). Though elites use authority to consolidate power and control, non-elite members of society retain at least some level of power no matter their place in the hierarchical or heterarchical order, and with it the ability to resist elite authority (McIntosh 1999). Dispersed power is also materialized in the archaeological record through architecture (Blanton and Fargher 2011; DeMarrais 2007; Kristiansen 2007; Monroe 2010), trade goods (Monroe 2013), ceramics (Dueppen 2015; Kohring et al. 2007; Wynne-Jones 2007), and more. Craft goods provide an ideal lens through which to study these complex relationships, as production, exchange, and use patterns encode socially relevant identities and connections on multiple scales.

Costin (1991) provided a classic scheme for conceptualizing the framework of craft production in order to explicate these issues with archaeological data. The degree of craft specialization expresses, in broad terms, the ratio of producers to consumers, and the type of specialization is considered in four dimensions: the context of production, on a scale from fully independent specialists to those 'attached' or fully dependent on the sponsorship of a government or institution; the concentration of production, from nucleated to dispersed; the scale of production, with goods being made primarily for 
kin on one extreme and modern wage labor on the other; and the intensity of production, from casual and part-time to full time and the exclusive means of economic support. Costin (1998:8) warned that the identity of the craft producer will not be a simple matter of age, gender, or affiliation, but essentially related to the "autonomy, control, power, privilege, and prestige" of their position in society. As Schortman and Urban (2004) argued, craft products possess value beyond the economic, and the identities of the people making them is not always defined in terms of their relationships to elites or each other, but rather are multiscalar and dynamic. Elites can engage in the consumption of craft goods without creating monopolies that result in dependence of craftspeople, who lose control over the exchange and consumption patterns of their produced goods. Inequality is one of many variables in this approach, and goods which are used to enforce political domination can also be used to resist it.

How these relationships and identities become encoded in ceramics is best examined through the concept of "technological style" (Lechtman 1977) as a reification of behaviors that take on particular patterns because of how they are shaped by society (in ways both recognized and unrecognized by members of that society). In this way, the concept of style cannot be divorced from that of function, as style is present in every aspect of how an object is made (Chilton 1999). Rather, distinctions must be drawn among the various stages of production and even further to distribution, use, and discard, as each of these processes is subject to its own variables. The chain of mutually contingent decisions that dictate technological style is known as the chaineoperatoire, or operational sequence, of craft production (Lemonnier 1992, 1993). Every action taken by the craftsperson is part of this chaine-operatoire, though only some of these actions will be apparent from the final product.

The problems, then, are to identify traits in any given collection of pottery that correspond to specific stages of the ceramic chaine-operatoire and recognize how these traits encode the social context of the potter. Through ethnographic work in southern Cameroon, Gosselain (1998) found a strong correlation between language group and the method used for vessel formation. The reason for this is crucial to the concept of a technological style: vessel formation was the portion of the learning process where new potters had the most in-depth, hands-on, and prolonged instruction from their teachers. As knowledge of pottery manufacture was passed down through time, and the populations of certain ethnic groups moved through space, this particular stage in the chaine-operatoire was preserved due to the private and personal nature of its transmission. Being a relatively early stage in the creation of the pot, vessel formation is difficult to recreate simply by seeing a finished pot. This stands in direct contrast to stages like decoration, where established potters can easily adopt or adapt techniques they observe on pots with or without direct contact with the original producer (Gosselain 2000).

Compositional data, as used in this study, most directly address the first two stages of the chaine-operatoire, raw material procurement and paste preparation, with exchange patterns possible to infer after clay sources are successfully identified. As an operational stage, the procurement of clay is somewhat intermediate between conservative and malleable, with several variables at play. Although clay is often widely available in a landscape, different occurrences of clay can be of varying quality. While it may seem prudent to assume that potters will use the highest quality clay available within a reasonable distance, this is not necessarily borne out by ethnographic data. In a study on Kalinga potters in the Philippines, Stark and colleagues (2000) found that the clay source a potter used was highly contingent on personal relationships, and did not 
correlate with the clay's plasticity. Michelaki, Braun, and Hancock (2015; 2012) examined all the possible clay sources near a Neolithic site to investigate not only which were used, but which were not. They determined that a cultural concept of what constitutes an appropriate source for pottery material was of paramount importance, with some high-quality clays available near coastlines ignored in favor of inland clays considered more socially appropriate to the task.

Once identified, a ceramic compositional signal can then provide information on the movement of pots across landscapes. Minc (2006, 2009; Minc et al. 2016) has used INAA compositional data to map the dynamic market economy of the Basin of Mexico, finding that sub-regional exchange patterns persisted during integration into the wider Aztec market economy. Stahl and colleagues (2008) found patterns of change in ceramic composition over two millennia in western Ghana that did not match the region's working chronology, making straightforward explanations impossible. They suggested that technological styles and exchange relationships were dynamic rather than directional, with some clay sources and consumption patterns fluctuating over time while others were maintained. A large trace element analysis project on pottery from the Iranian region found that the composition of potters' tools did not match the geology of the location in which they were found, indicating that Proto-Elamite potters were highly mobile, traveling long distances to practice their craft (Alden and Minc 2016). A subset of this pottery from an Uruk colony in western Iran demonstrated that Uruk-style vessels were made with local clays and that the colonists engaged in trade with local and nearby communities (Gopnik et al. 2016). Quite recently, Grave and colleagues (2017) found that INAA was able to differentiate between products of different kilns in Cambodia where X-Ray Fluorescence (XRF) could not, laying the groundwork for investigation into pottery consumption patterns in Khmer society.

Compositional analysis of ceramics can provide data on clay sourcing and paste preparations, the first two major stages of pottery production (Arnold et al. 1991; Neff et al. 1988, 1989). These sources can be identified with various degrees of precision in different geological and cultural contexts to assist in understanding the nature of past ceramic economies. The degree of specialization observable in chemical and other traits of pottery has important ramifications for the organization of production in political economies. The social status of ceramic producers, their relationships with other economic specialists, their multiscalar identities, and the prestige of their craft can all be supported by evidence of the geochemical variation observed in pottery.

\section{GEOCHEMICAL ANALYSIS}

A total of 42 sherds from the pit feature at P'ungnap T'osŏng and 30 sherds from residences at Kwangju were subjected to INAA and subsequently divided into two major groups based on geochemical composition. The processing of sherds and statistical handling of the data are outlined in the Methods section below. The distinction apparent between these groups can be seen in Figures 2 and 3, with the majority of sherds from each site forming a group that more or less excludes the sherds from the other. The first group contains mostly sherds from P'ungnap T'osong and is called the 'Hansŏng' group, since, as is explained below, most constituent sherds were likely not produced at P' ungnap T'osŏng itself but elsewhere in the Hansŏng Paekche region. The second group contains mostly sherds from Kwangju Palsan, so is called 


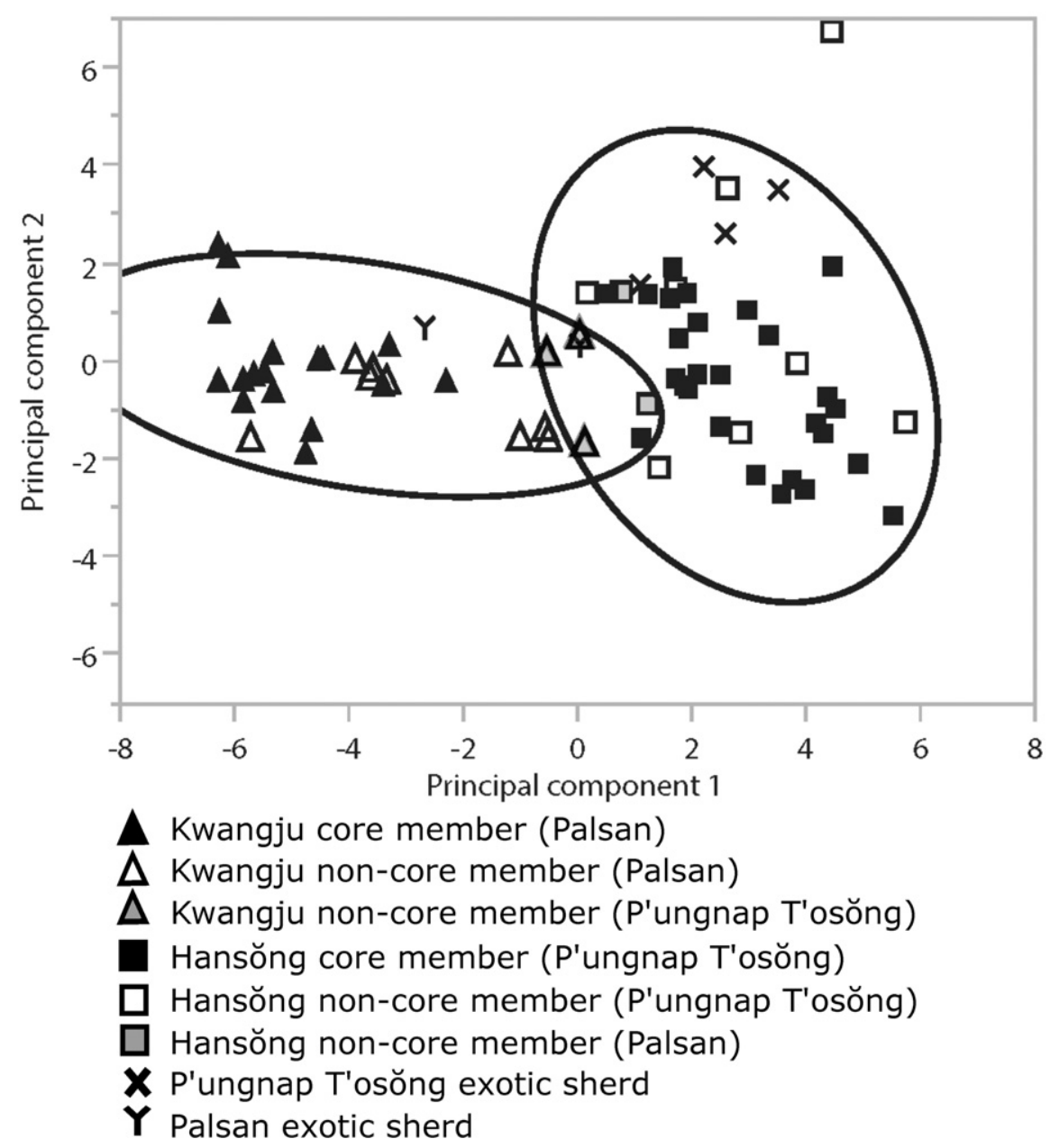

Fig. 2. Bivariate plot of principal components 1 and 2. Groups are shown with 95\% confidence intervals including all members.

'Kwangju'. Three sherds from P'ungnap T'osŏng tested into the Kwangju group and two from Palsan tested into Hansŏng. Table 1 provides a list of all sherds that were not assigned to the composition group corresponding to their site of origin.

The sherds from Kwangju Palsan that form the Kwangju composition group $(n=26)$ are mostly yŏnjil earthenware, often with grid-paddled decoration. A subset of this group consists of three kyŏngjil and intermediate sherds that share a distinct chemical pattern within the range of variation for the Kwangju group. This subset, called the 'Kwangju stoneware group' below, also closely resembles the Kwangju group sherds from P'ungnap T'osŏng when viewed in parallel coordinate plots showing compositional profiles (Fig. 4).

Two Kwangju Palsan sherds contain the high transition metals (particularly Sc, V, and $\mathrm{Cr}$ ) and rare earth elements (i.e., La, Ce, Sm, Eu, Tb, Dy, Yb, Lu) consistent with northern sherds, so were assigned to the Hansŏng group. These sherds are of intermediate and yŏnjil hardness and one is grid-paddled. Of the 34 sherds from 


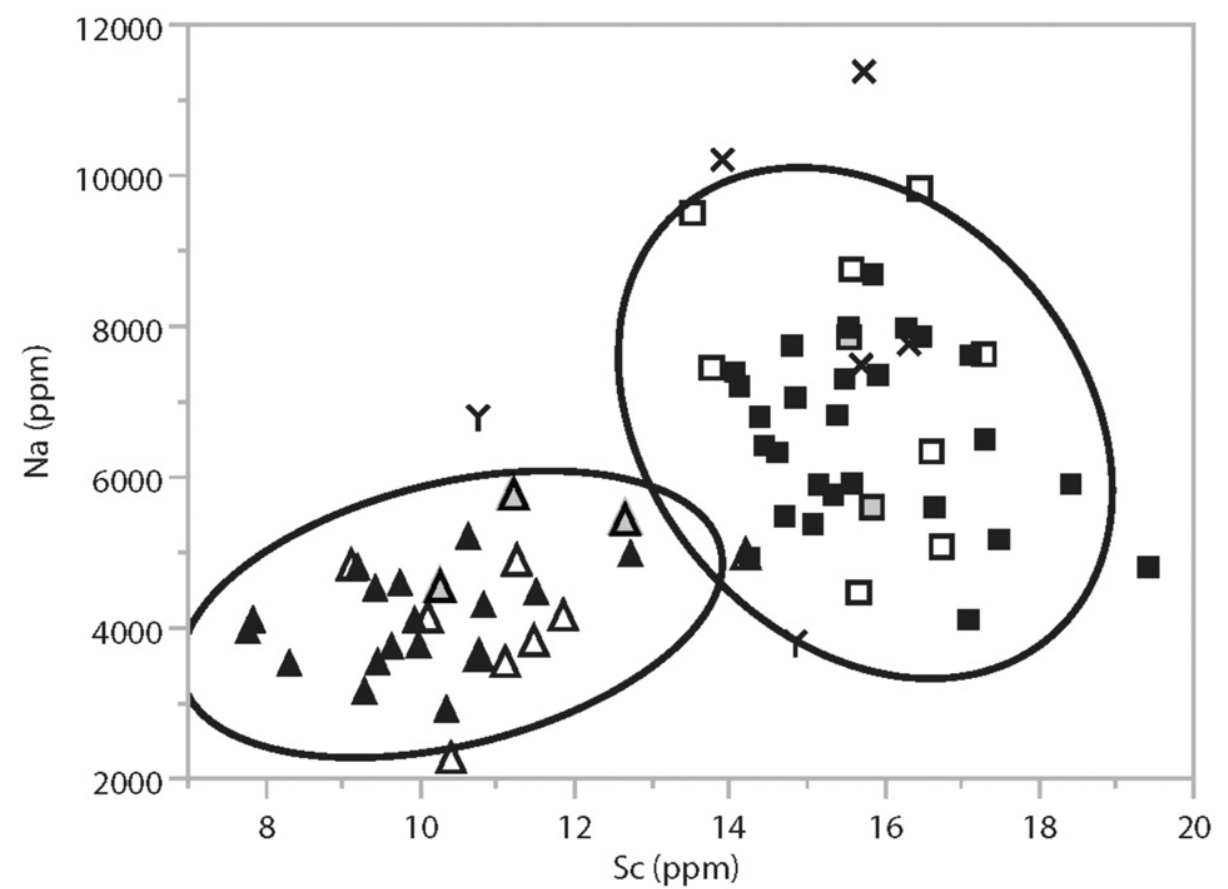
A Kwangju core member (Palsan)
$\Delta$ Kwangju non-core member (Palsan)
$\triangle$ Kwangju non-core member (P'ungnap T'osŏng)
Hansŏng core member (P'ungnap T'osŏng)
Hansŏng non-core member (P'ungnap T'osŏng)
Hansŏng non-core member (Palsan)
$\mathbf{X}$ P'ungnap T'osŏng exotic sherd
$\mathbf{Y}$ Palsan exotic sherd

Fig. 3. Bivariate plot of the chemical components sodium and scandium. Groups are shown with $95 \%$ confidence intervals including all members.

P'ungnap T'osŏng assigned to the Hansŏng group, only two are yŏnjil, with t'analmun paddling and stamped parallel lines the most common decorative techniques. A chemically distinct subset is visible within the Hansŏng group as it was in Kwangju, this time consisting of 16 sherds of intermediate or kyongjil hardness. Comparison with INAA results from other Korean sites determined the production origin of this group to be the kiln complex at Sansu-ri/Samnyong-ni (Walsh 2017), so this subset is referred to as the 'Hansŏng Sansu-ri' group. All sherds in this subset are kyŏngjil or intermediate in hardness, but they are otherwise not of consistent appearance or quality. Two sherds show obvious if not catastrophic flaws: one sherd has a large mineral inclusion breaking through to the exterior surface, with a pattern of cracks surrounding it roughly $1 \mathrm{~cm}$ across; another has an air bubble roughly $2 \mathrm{~cm}$ in diameter, probably from expansion during the firing process. Six have evidence of the parallel line stamping associated with Sansu-ri production, one shows cord-wrapped 
Table i. List of Sherds Placed into Composition Groups not Matching their Site OF ORIGIN

\begin{tabular}{lllll}
\hline SHERD & SITE & COMPOSITION GROUP & \multicolumn{1}{c}{ HARDNESS } & \multicolumn{1}{c}{ DECORATION } \\
\hline L02 & P'ungnap & None (exotic) & Intermediate & Parallel lines \\
L09 & P'ungnap & Kwangju & Yŏnjil (earthenware) & None \\
L11 & P'ungnap & None (exotic) & Intermediate & Dragged comb \\
L13 & P'ungnap & None (exotic) & Yŏnjil (earthenware) & Cord-wrapped paddling \\
L19 & P'ungnap & None (exotic) & Yŏnjil (earthenware) & Cord-wrapped paddling \\
L24 & P'ungnap & None (exotic) & Intermediate & None \\
L25 & P'ungnap & Kwangju & Intermediate & None \\
L41 & P'ungnap & Kwangju & Kyŏngjil (stoneware) & Carved grid paddling \\
P04 & Palsan & None (exotic) & Kyŏngjil (stoneware) & Slip \\
P15 & Palsan & None (exotic) & Yŏnjil (earthenware) & Carved diamond paddling \\
P16 & Palsan & Hansŏng & Intermediate & Possible paddling \\
P28 & Palsan & Hansŏng & Yŏnjil (earthenware) & Carved grid paddling \\
\hline
\end{tabular}

t'analmun paddling, two have a mottled glaze on their exterior surfaces, and one has the dark and shiny surface of a mayŏn blackware.

Five sherds from P'ungnap T'osŏng and two from Kwangju could not be assigned a geochemical group and are considered exotic to the regions. The five exotics from P'ungnap T'osŏng are of various hardness, and decorations include cord-wrapped t'analmun paddle marks and parallel lines of unclear application technique. Chemically, these sherds are highly variable, with two showing unusual levels of aluminum, calcium, and potassium that suggest a fundamentally different geologic origin. One of the Palsan exotics shows peaks in iron and chromium that are unique to any sherds even in the larger Korean assemblage of 290 examined by Walsh (2017). This sherd also shows a slipped surface treatment that does not appear on other kyŏngjilsherds at Palsan. The other is a yŏnjil sherd unusually low in transition metal content, including titanium, scandium, vanadium, and chromium. While this sherd bears grid-paddled decoration, the grid is more diamond in shape than square or rectangular. These findings are summarized in Table 2.

\section{DISCUSSION}

The two composition groups identified above demonstrate that geochemical differentiation is possible among clay sources in the Korean peninsula. Production signatures from the sites of Palsan and P'ungnap T'osŏng, nearly $300 \mathrm{~km}$ apart, are readily distinguished with multivariate analysis. The variation within these composition groups cannot be fully understood before the completion of clay survey in the vicinities of both sites, but certain patterns are clear in the current data. Both the Kwangju and Hansŏng composition groups contain subsets of sherds that are markedly similar in chemistry, suggesting not only a common origin but potential standardization of production (Arnold 2000). In the case of the Hansŏng group, this can be traced to a specific production location, the Sansu-ri kiln complex roughly $75 \mathrm{~km}$ southwest of P'ungnap T'osŏng. As these sherds still clearly fall into the chemical parameters of the Hansŏng group as a whole, the geographical range of potential production locales in these composition groups must be understood as fairly 


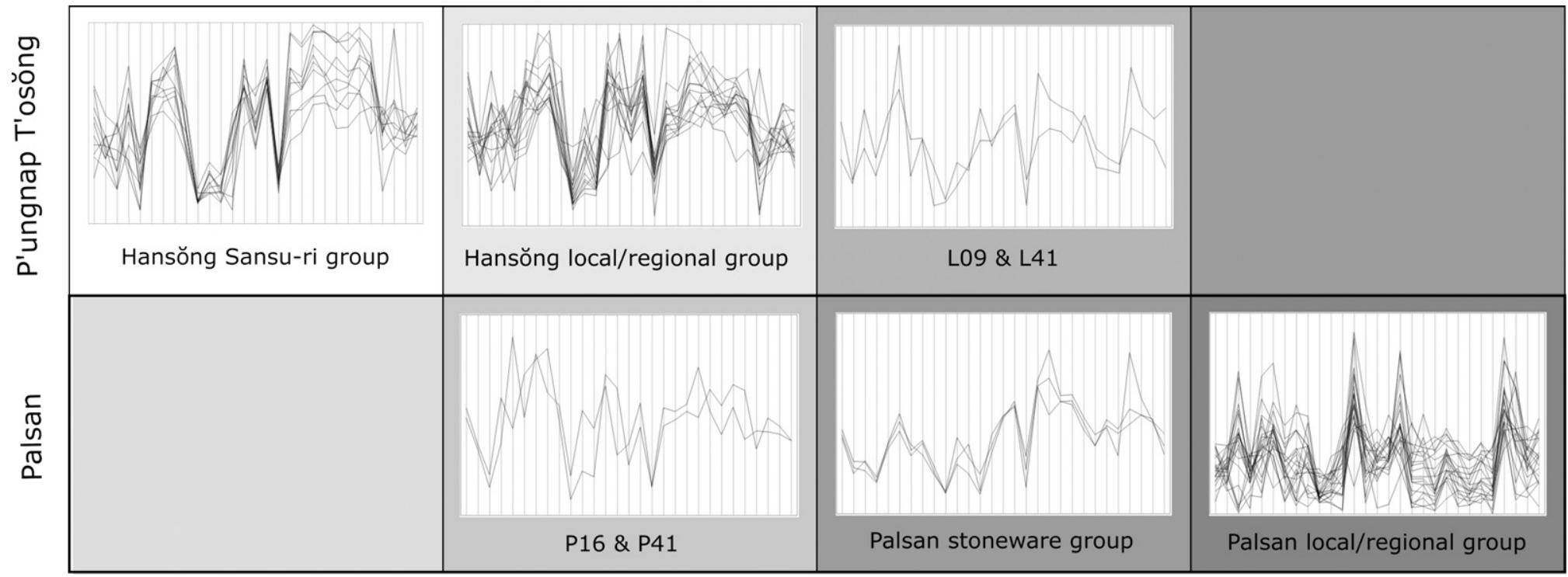

Fig. 4. Parallel coordinate plots showing profiles of selected composition groups. Each parallel line represents one of 29 elements, in order: $\mathrm{Al}, \mathrm{Ca}, \mathrm{K}, \mathrm{Na}, \mathrm{Fe}, \mathrm{Ti}, \mathrm{Sc}$, V, Cr, Mn, Co, Zn, As, Sb, Rb, Cs, Ba, La, Ce, Sm, Eu, Tb, Dy, Yb, Lu, Hf, Ta, Th, U. 
Table 2. Relative Composition of YŏnjIL and KyŎngjIL Sherds in P'ungnap T'osŏng and

Kwangju Palsan Samples, and Interpretation of Sherd Composition Groups as Generalized Production, Specialized Production, or Exotics

\begin{tabular}{|c|c|c|c|}
\hline SITE & $\begin{array}{l}\text { YŎNJIL SHERDS } \\
\text { N (\% OF TOTAL) }\end{array}$ & $\begin{array}{l}\text { INTERMEDIATE HARDNESS SHERDS } \\
\text { N (\% OF TOTAL })\end{array}$ & $\begin{array}{l}\text { KYŎNGJIL SHERDS } \\
\text { N (\% OF TOTAL) }\end{array}$ \\
\hline Kwangju Palsan & $23(77 \%)$ & $4(13 \%)$ & $3(10 \%)$ \\
\hline P'ungnap T'osŏng & $5(12 \%)$ & $12(28.5 \%)$ & $25(59.5 \%)$ \\
\hline \multirow[t]{3}{*}{ SITE } & GENERAL REGIONAL & SPECIALIZED REGIONAL & LONG-DISTANCE \\
\hline & PRODUCTION & PRODUCTION & IMPORTS \\
\hline & $N(\%$ OF TOTAL $)$ & $N(\%$ OF TOTAL $)$ & $N(\%$ OF TOTAL $)$ \\
\hline Kwangju Palsan & $23(77 \%)$ & $3(10 \%)$ & $4(13 \%)$ \\
\hline P'ungnap T'osŏng & $18(43 \%)$ & $16(38 \%)$ & $8(19 \%)$ \\
\hline
\end{tabular}

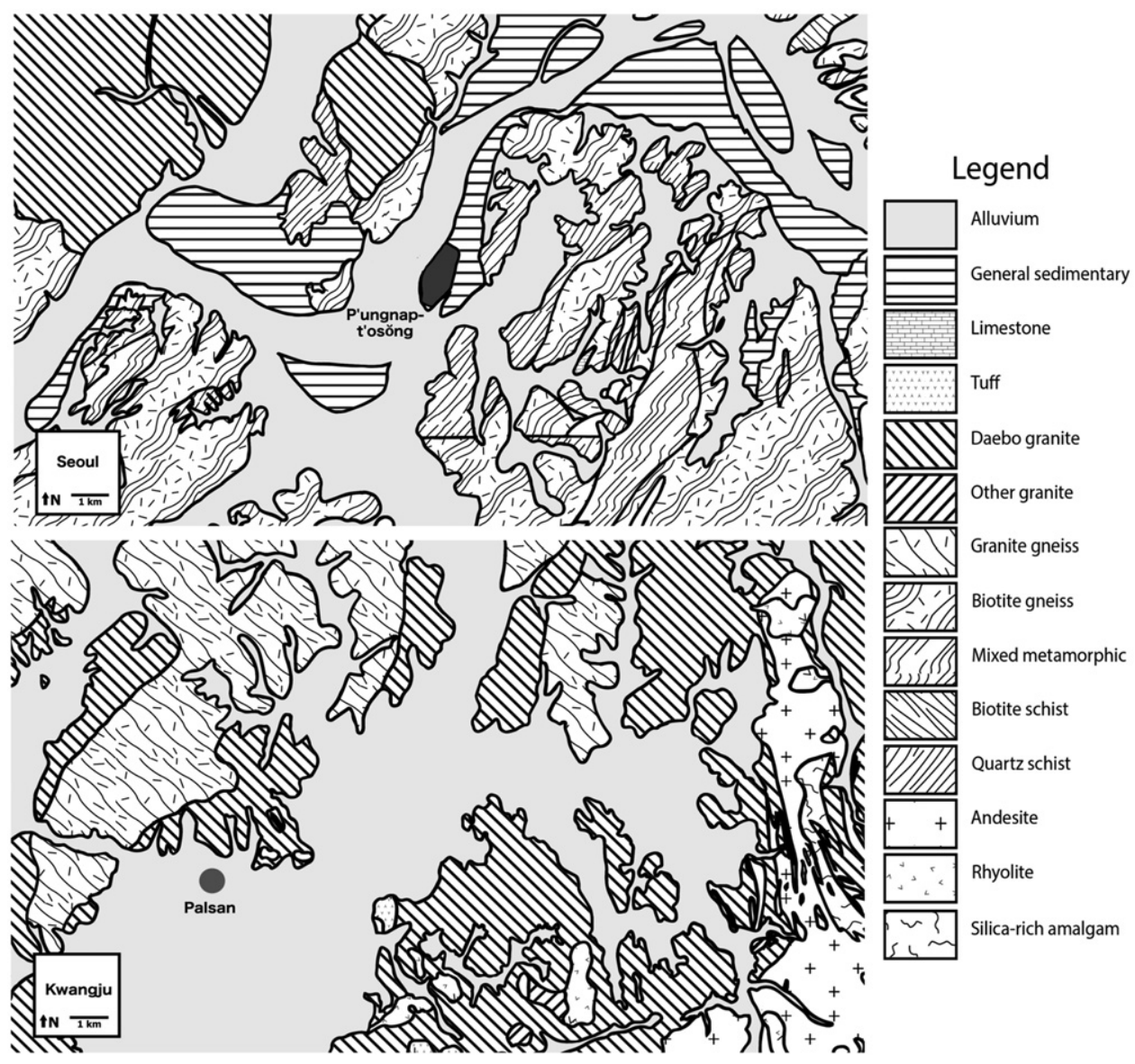

Fig. 5. Geological maps of Seoul (top) and Kwangju (bottom) regions, showing relatively granite-rich environment surrounding Kwangju, contrasting with extensive sedimentary and metamorphic deposits in Seoul. 
large. This homogeneity could be due to the extent of geological formations such as Daebo granite and the Gyeonggi Metamorphic Complex (Fig. 5), cultural preferences for clay with certain qualities, or a combination of both. For now, the operating assumption is that sherds in the Hansŏng group could potentially have been produced anywhere in the territory controlled by Hansong Paekche and those in the Kwangju group anywhere in Chŏlla Province.

The composition groups and their subsets speak to practices surrounding craft specialization and standardization in their respective societies. The Hansŏng Sansu-ri and Kwangju stoneware subsets meet the essential criterion for standardization (Blackman et al. 1993; Underhill 2015), that is, a reduction in variety. These sherds are less variable in hardness (with no yonnil represented in either subset) and in the chemical makeup of their raw materials. In terms of chaine-operatoire, this indicates that the choices craftspeople were making when gathering clay, preparing paste, and firing pots were stable in these contexts, with the same decisions made repeatedly through time and by numerous individuals. This kind of standardization can be used as proxy evidence for specialization; the identification of the Sansu-ri production signature makes this particularly straightforward. The large number of kilns and workshops excavated at Sansu-ri (Hannam 2006) and the lack of chemical variation in the pots recovered there (Walsh 2017) provide a strong connection between standardization and specialization in Hansŏng Paekche. Given its chemical similarity in the midst of variation, the same logic can be applied to the Kwangju stoneware group, though Arnold (2000) has cautioned that social and geological factors affecting the availability of raw materials can interfere with such interpretations. In this case, the lack of younjil sherds in the subset when the vast majority of sherds sampled from Palsan were yŏnjil makes it more likely that these pots came from specialized producers, rather than ones who had only extremely limited access to raw materials. Such specialization has a basis in evidence from Chŏlla Province, where kilns appear mainly at very large and very small sites (Kim S. 2014). If sites with kilns next to $2-5$ houses were the locus of specialized pottery production, the Kwangju stoneware group might well have originated from such a site.

At both Palsan and P'ungnap T'osŏng, the ceramics that were produced in the immediate region fall into two groups: generalized production, typified by sherds of various hardness that show relatively more variation in geochemistry; and specialized production, kyŏngiil and intermediate sherds with extremely similar chemical signatures (Table 2). This pattern is evident at a larger scale in P'ungnap T'osŏng, where high-fired (if not always flawless quality) pottery was brought into the city over a $75 \mathrm{~km}$ distance. The distance involved in moving the Kwangju stoneware group sherds into Palsan cannot currently be determined, but if specialized production did indeed take place at small sites, this pottery was at least from outside the settlement's immediate vicinity. Specialized craftspeople may choose to practice their trade in locations near their preferred raw materials, and clay quality is certainly not uniform across a landscape. There is no reason to believe, however, that an appropriate source of clay was not available closer than $75 \mathrm{~km}$ from P'ungnap T'osong, or that a kiln complex could not have been established nearer to the fortress. Similarly, high-fired pottery could have been produced at large settlements in the Mahan, but evidence suggests its production was restricted to small, specialized locales (Kim S. 2014). Pottery is both heavy and fragile, and the Korean peninsula is mountainous, but as Costin (1991) has pointed out, transportation costs can add to the value of craft goods. 
If the purpose of keeping major ceramic production centers away from major settlements was to increase their value, this would appear consistent with the use of Sansu-ri vessels in elite feasting activities at P'ungnap T'osŏng, but does not explain the use of specialized stoneware pots at Palsan, where no elite connection is evident from the household contexts. As Paekche centralized as a state, it may have amplified existing Mahan strategies to the extent that we see in the relationship between Sansu-ri and P'ungnap T'osong. Another possibility, given that stoneware was not produced widely in Mahan cultures prior to C.E. 300, is that Palsan and other Mahan cultures adapted this practice from Paekche as their own production and use of stoneware increased. In either of these cases, the appearance of this pattern in both P'ungnap T'osŏng and Palsan suggests a set of cultural understandings about value and distance that was shared between these two communities and may have been common to all Mahan and Mahan-derived cultures.

The related factors of high firing temperatures, value, and distance in the standardized subsets of the Hansŏng and Paekche groups all point to the status of these ceramics as prestige, rather than utilitarian, wares. While the terminology has been flexible, this dichotomy is popular in archaeology as a way for examining changes in craft production and consumption when elite classes are present in a society (Costin 2001; Hayden 1998; Helms 1993; Junker 1999; Peregrine 1991). As Flad and Hruby (2007) pointed out, however, the labels 'prestige' and 'utilitarian' are not mutually exclusive when applied to objects. Making a thing into a symbol of power or prestige requires its use as such, so is contingent on behaviors involving the object that are recognized as meaningful in social context. A craft good can therefore be highly prestigious at one moment and wholly utilitarian the next, so the attempt by archaeologists to identify one class of ceramic vessels as either prestigious or not is often misguided. Costin (2007) went so far as to say that the concept of value should be replaced with that of function to shift focus onto observable patterns of consumption rather than artifact traits that may signify more to the archaeologist than to the community that produced and used these objects. Though the Kwangju stoneware group pots were not recovered from obviously prestigious contexts, they may have been highly prestigious goods at specific points in their use lives. This status would likely have been temporary; after a vessel had served its prestige function, it might have become available for use by any Palsan resident. In stark contrast, the prestige function of these specialized goods at P'ungnap T'osŏng involved their burial, which cut off all possibility of future usage.

As opposed to the specialized pottery produced in the Hansŏng and Kwangju regions, pottery imported from other societies was not consistently high-fired or otherwise obviously prestigious. The social context of exchange over inter-societal distances may have been different from internal political economics, focusing more on human interaction or the contents of the containers than the pots themselves. Economic exchange can be manipulated by elites for a variety of purposes (Brumfiel and Earle 1987; Hirth 1996; Smith 2004; Vaughn 2006), but these purposes have generally required class-based restrictions on consumption. The existence of such restrictions are not necessarily supported by Mahan/Paekche data, where even Sansuri vessels have been excavated from a variety of sites and contexts (Sŏng 2012, 2016). Helms (1993) emphasized long-distance exchange as a venue for elites to reinforce their connection to places both literally and figuratively beyond, but this need not be restricted to elites. Pailes (2016) demonstrated that emergent elites need not monopolize long-distance exchange networks and that complexity can involve 
small-scale exchanges of relatively mundane goods in order to maintain social alliances. Long-distance trade may have been an essential component of Mahan identity, as seen with the keyhole-shaped tombs discussed above (Lee 2014), and historical records of exchange with Chinese and other nearby societies (Best 2006). Inter-societal exchange was also crucial to Paekche statecraft, as the ritual feasting pit at P'ungnap T'osóng contained pots from Mahan territories and unknown long-distance origins alongside vessels from Paekche territories. In this case, the symbolism of the objects was far from ephemeral, and Paekche elites sent the message that they had particular access to and control over these connections.

Just as exchange relationships with distant communities reinforced social ties in a way that could be wielded as cultural capital, the non-centralized production of specialized ceramics would have served to maintain domestic cohesion economically, politically, and socially. At Palsan, this fits with the historical picture of a Mahan polity as a political unit with a distinct identity, where villages and towns with a dispersed power structure maintained unity through various rituals and events (H. Yi 2009). Some level of town sponsorship may have been involved in kyongjil production to ensure that specialists had the means to make these wares and bring them into town, but the pots themselves were not as important as the practice of this exchange.

Multiple scales of physical distance were involved in the interactions revealed by patterns of geochemical composition; the value of these distances is also multi-scalar and dynamic. While long-distance exchange is evidenced at these sites, the value of distance also plays out on the intra-societal level, with the production of kyonggil occurring away from major population centers at P'ungnap T'osŏng and potentially Palsan for the purpose of social alliances and territorial integration. At the same time, choosing to have kyŏngjil rather than yŏnjil produced at this distance was closely related to a cultural sense of appropriateness for special things to come from outside the immediate community. This pattern is suggested by the limited data currently available from Mahan settlements, where evidence for strict social classes and centralized leadership is lacking; it becomes starkly visible in the Paekche period, where the same cultural underpinnings of prestige in distance were used by elites to consolidate political control.

Several important similarities and differences in pottery production and use have been identified for the sites of Kwangju Palsan and P'ungnap T'osŏng. A specialized pattern of production for kyongjil was common to both sites, though at a much larger scale at P'ungnap T'osŏng. The much higher rate of specialized kyŏngjil versus generalized yŏnjil at the Paekche fortress, as well as the great distance between producer and consumer, provides evidence for how Paekche intensified its craft economy and notions of elite identity to suit the needs of an expansive kingdom. The similarity in consumption patterns at Palsan and P'ungnap T'osŏng, including evidence for noncentralized production of highly valued craft goods and the importance of longdistance trade, suggests a locally articulated form of social complexity based in sensibilities common to both societies.

\section{METHODS}

Each sherd in this study was prepared for INAA at the TRIGA reactor at Oregon State University's Radiation Center by removing exterior portions with a tungsten carbide burr, pulverizing approximately $2.5 \mathrm{~g}$ of the remaining material, and placing approximately $250 \mathrm{mg}$ of each sample in a vial for neutron bombardment. By placing 
samples near the reactor core and irradiating them with extra neutrons, this process creates artificially radioactive isotopes of elements present, whose identity and abundance can be determined precisely from their decay products. A suite of 30 elements was measured through multiple counts of resultant gamma activity over several weeks following irradiation. Element concentrations were determined through comparison with three replicates of a known standard material, NIST1633A (coal fly ash). For more information on irradiation and data protocols at the OSU reactor, see Minc (2016). The full results are available in Appendix A (aluminum through rubidium) and Appendix B (cesium through uranium).

INAA is a firmly established method for detecting geochemical variation in archaeological ceramics, but its application to Korean material is fairly novel and presents certain challenges (Cho 2006; Kwŏn and Kim 2008). Firstly, the differentiation of soil groups is likely to be subtle, as the Korean peninsula is built primarily of granites created in large-scale orogenic events, resulting in similar soil chemistries from sometimes far-flung regions (Dong et al. 2015). A particular Jurassic granite known as the Daebo formation appears in much of the Mahan/Paekche region, including the areas around Kwangju Palsan and P'ungnap T'osŏng (Han'guk 2016). Granite, a felsic, intrusive igneous rock, weathers well into clay and tends to be high in silica and potassium, but the frequent presence of granite in the geological landscape can be a homogenizing factor for Korean clays. As seen in Figure 5, the site of Palsan is located on alluvium surrounded by Daebo granite and Precambrian granite gneiss (Chough 2013; Han'guk 2016), but P'ungnap T'osŏng lies on sedimentary rock with the nearest granite roughly $3 \mathrm{~km}$ across the Han River. Therefore, despite the granitic mountain sources of Korean rivers, the clay weathering processes at these two sites likely included mineral contributions from multiple and distinct geological sources, creating a degree of chemical dissimilarity detectable through INAA.

The second major challenge in this study is the lack of comparative materials, either from previous archaeological studies from Korea or the geologically similar Chinese mainland or direct clay samples from the area around the sites. The latter is actively being addressed with further fieldwork, while the former two will simply require continued research along these lines. For this article, the paucity of comparative material means that those groups that can be identified have only each other for context, making the social meaning behind their chemical variation difficult to parse.

Sample size, which is limited by the number of sherds excavators are willing to submit to destructive analysis, presents a third challenge. A sample of 42 sherds was obtained from a single feature at P'ungnap T'osŏng. Pit 170, in the central Kyŏngdang area of the site, has not yet been included in the published site reports, but includes the refuse of ritualized feasting activities. Similar features excavated in the same year, Pits 196 and 206, contained typical Paekche jars, bowls, and cooking pots, as well as a small number of glazewares (Hansŏng and Hansin 2011). The sherds in this sample are those that remained after more intact pots from Pit 170 had been pieced together, so these sherds were sampled with the primary goal of avoiding the collection of two sherds from the same pot. Each sherd was determined to be visually dissimilar from the others in some way. While this cannot entirely rule out the possibility of cross-sampling, no major concerns were later raised by the INAA results. The sample from Kwangju Palsan is comprised of 30 sherds from 29 different house features. These sherds were collected with the goal of creating an approximately representative sample of Palsan ceramics. This strategy effectively eliminates the possibility that any two sherds originated from the same vessel. 
Despite the limitations presented by a relatively high degree of geological uniformity, lack of a comparative dataset, and sampling issues, the INAA data on these 72 sherds were sufficient to distinguish groups using multivariate analysis. The initial detection of groups was done through Principal Components Analysis (PCA), a multivariate method that finds the maximum variation in a dataset when plotted in $n-$ dimensional space, and comparison of these results with bivariate plots of elements. For this analysis, parts per million values for all INAA data were utilized with the exception of the results from neodymium, which were deemed unreliable in this case. As seen in Figure 2, two major groups appear in a plot of the first two principal components (the two greatest axes of variation), and promisingly, membership in either group is strongly correlated with the sherds' site of origin. These distinctions held true through examination of bivariate plots of individual elements and core group membership was then determined (illustrated in Fig. 2, Fig. 3). A total of 27 sherds were placed into the Hansŏng group (for pottery most likely produced in the Hansŏng Paekche region) and 17 into the Kwangju group (likely originating from producers in and around modern Kwangju). Three sherds from P'ungnap T'osŏng (L09, L25, and L41) fell within the parameters of the Kwangju group, but were not included as core group members, in order to be as conservative as possible given the lack of comparative material. The same was true for two sherds from Palsan (P16 and P28), which were not included as core members of the Hansŏng group despite their chemical similarities.

With the core geochemical groups identified, group membership was rigorously tested and, when possible, remaining sherds were placed in either Hansŏng or Kwangju. Data for each sherd (transformed into log10 values) were tested using Mahalanobis Distance (MD), a measure of distance from a multivariate group centroid that allows the calculation of probability for membership without assuming that each observation (sherd) must belong to a defined group (Neff 2002). The major limitation of this test is that the number of group members should ideally be several times the number of variables with which the centroid is calculated. Some researchers reduce dimensionality by using Principal Component scores as variables in MD calculation, but this was deemed inappropriate for this dataset as the two groups are only effectively separated by the first principal component and including more components could add noise to the results. Using geochemical data rather than statistical results also reduces mathematical abstraction, our preference as these data are intended as the beginnings of a large comparative collection and the origins of variability are not yet fully understood. The elements used were therefore reduced by stepwise discriminate analysis, resulting in the selection of six elements that represent bulk and trace minerals that best distinguish between the core groups: Al, Na, Sc, Cr, La, and Ta. These results were treated with caution. Though no outliers were found within the core groups, we remain aware that the reduction of variables reduced the likelihood of outlier identification. Using MD results to assign non-core members to groups must also be undertaken with care. In fact, 13 additional sherds tested into the Hansŏng group with $p \geq 0.05$, but several of these were rejected when placed back into full dimensional context in the PCP (Parallel Coordinate Plot) compositional profile analysis below. Eight additional sherds were initially assigned to the Kwangju group, only one of which was later rejected, perhaps indicating a more unified geochemistry for this southern region. MD failed to classify several sherds that appear geochemically consistent with either the Hansŏng or Kwangju group when viewed over the full set of variables. With the present data, the limitations of MD analysis cannot be fully 
overcome, but this method has provided a basic check on the core groups as well as initial insights into exchange patterns between these two sites. One sherd from Palsan (P16) could be added to the Hansŏng group and one from P'ungnap T'osŏng (L09) to the Kwangju group on the basis of MD scores.

Further analysis was necessary to refine and expand group membership. Linear Discriminant Analysis (LDA), which uses Mahalanobis distance but attempts to place every observation into a defined group, placed both Palsan sherds suspected to be Hansŏng group members (P16 and P28, discussed above) into that group, and placed the expected three P'ungnap T'osŏng sherds (L09, L25, L41) into Kwangju. The remaining sherds were simply placed in the group corresponding to their site of origin by LDA. The reduction of variables necessary for LDA caused problems as with MD, and so within-group variation was visualized using Parallel Coordinate Plots. PCPs visualize multivariate data by plotting each observation along $n$ parallel lines, making patterns readily apparent (Fig. 4). This technique is well-suited for data with variables at different scales, since PCPs can be generated from parts-per-million values without transformation. The use of PCP visualization to create a compositional profile of each sherd is adapted from the "spider diagram" routinely employed by geologists for evaluating chemical data (Rollinson 2014; see also Minc 2016 and Minc et al. 2016 for their use in archaeological ceramics). As in these studies, elements are ordered and plotted by geochemical group (i.e., major elements, transition metals, alkali elements, rare earth elements, and high field-strength incompatibles).

When visualized in this way, the distinctions between the Hansŏng and Kwangju groups across all 29 elements are easy to detect, and the limitations of PCA, MD, and LDA are mitigated. As shown in Figure 4, the placement of three P'ungnap T'osŏng sherds in the Kwangju group and two Palsan sherds in Hansŏng was confirmed. Importantly, five sherds from P'ungnap T'osŏng and two from Palsan showed little resemblance to other sherds in the dataset and were therefore considered exotic material. Most of these sherds had been placed into a composition group by MD, but with relatively low probabilities of group membership. (The highest, sherd L13, had a $p=0.154$ association with Hansŏng and $p=0.015$ with Kwangju, but shows peaks in chromium and cobalt inconsistent with either group.) All other sherds could be made non-core members of Hansŏng or Kwangju, as chemical variations that had excluded them in PCA or MD were relatively minor when viewed in PCP. For example, one P'ungnap T'osŏng sherd, which landed far outside the 95\% density ellipse in PCA (see the empty square on the extreme upper right of the graph in Fig. 2), had an extremely high quantity of manganese, an element which tends to occur in discrete concretions, but was an otherwise entirely typical Hansŏng sherd.

The relatively small sample sizes in the current study proved advantageous in PCP analysis, making further distinctions possible within the major composition groups. Three sherds from Palsan showed nearly identical chemical signatures, forming a clear subgroup within the range of Kwangju compositional variation. A group of 16 sherds from P'ungnap T'osŏng showed a strongly cohesive signal, one that matches the PCP of a sample of 32 sherds taken from the contemporaneous kiln complex site of Sansu-ri/ Samnyong-ni (Walsh 2017). Discussion of the Sansu-ri assemblage is outside the realm of the current article, but no other multivariate method was able to consistently make this distinction, though the pattern is clear when viewed as compositional profiles in PCP.

The reliability of these tests as applied to Korean ceramic data will only increase as the comparative dataset expands, but at present the use of methods employing either the full or reduced set of variables support each other to enable the formation of geochemical groups. 
Appendix A. INAA Data, Aluminum through Rubidium

\begin{tabular}{|c|c|c|c|c|c|c|c|c|c|c|c|c|c|c|c|}
\hline INAA ID & $\mathrm{AL}$ & $\mathrm{CA}$ & K & NA & $\mathrm{FE}$ & TI & SC & $\mathrm{v}$ & $\mathrm{CR}$ & MN & $\mathrm{CO}$ & $\mathrm{ZN}$ & AS & SB & $\mathrm{RB}$ \\
\hline KOR_L01 & 105774 & 3603 & 25555 & 6342 & 22701 & 6223.3 & 16.61 & 117.26 & 126.1 & 138.48 & 10.57 & 93.91 & 4.24 & 0.8 & 161.94 \\
\hline KOR_L02 & 95512 & 5511 & 27147 & 9501 & 26456 & 5318.03 & 13.52 & 106.06 & 85.43 & 169.37 & 11.03 & 70.8 & 5.47 & 0.69 & 136.49 \\
\hline KOR_L03 & 102849 & 4157 & 21031 & 5915 & 42311 & 5920.7 & 15.58 & 130.18 & 90.51 & 509.15 & 14.33 & 64.64 & 3.7 & 1.09 & 133.46 \\
\hline KOR_L04 & 115886 & 3885 & 28279 & 6420 & 37888 & 5532.08 & 14.45 & 113.65 & 78.57 & 232.75 & 11.22 & 108.04 & 9.26 & 1.14 & 169.41 \\
\hline KOR_L05 & 115983 & 4836 & 23751 & 9827 & 24945 & 5955.01 & 16.46 & 137.92 & 95.04 & 145.86 & 9.35 & 60.22 & 0.88 & 1.27 & 144.77 \\
\hline KOR_L06 & 98448 & 2971 & 23880 & 5766 & 39529 & 6015.93 & 15.34 & 125.87 & 107.37 & 345.31 & 16.02 & 78.54 & 10.11 & 1.04 & 135.06 \\
\hline KOR_L07 & 101596 & 3942 & 23468 & 7207 & 43814 & 5697.4 & 14.13 & 115.34 & 76.58 & 260.28 & 18.58 & 67.96 & 11.79 & 0.95 & 138.84 \\
\hline KOR_L08 & 110016 & 2251 & 25800 & 4114 & 29385 & 6374.61 & 17.09 & 133.71 & 133.34 & 198.34 & 14.32 & 115.25 & 7.38 & 1.07 & 156.2 \\
\hline KOR_L09 & 95089 & 2718 & 25346 & 5421 & 39774 & 5890.67 & 12.65 & 94.1 & 75.54 & 176.88 & 11.29 & 73.51 & 7.65 & 0.84 & 151.09 \\
\hline KOR_L10 & 104989 & 2879 & 23813 & 4470 & 17985 & 5943 & 15.67 & 104.01 & 94.65 & 140.12 & 6.57 & 58.63 & 1.72 & 0.93 & 150.62 \\
\hline KOR_L11 & 102971 & 8431 & 23529 & 10207 & 31078 & 5203.81 & 13.91 & 101.52 & 75.49 & 281.82 & 8.65 & 101.01 & 6.01 & 0.79 & 131.51 \\
\hline KOR_L12 & 100641 & 5254 & 23505 & 7629 & 51228 & 5300.77 & 17.29 & 137.02 & 108.75 & 1224.66 & 29.44 & 120.18 & 9.67 & 0.88 & 134.33 \\
\hline KOR_L13 & 94529 & 5406 & 24257 & 7485 & 36281 & 5401.09 & 15.7 & 113.08 & 155.4 & 292.29 & 16.42 & 91.63 & 12.03 & 0.69 & 140.13 \\
\hline KOR_L14 & 98432 & 4389 & 21437 & 6500 & 30086 & 5812.08 & 17.3 & 126.88 & 119.33 & 272.85 & 16.83 & 83.36 & 5.18 & 0.94 & 113.52 \\
\hline KOR_L15 & 119336 & 3591 & 22018 & 5910 & 36353 & 5886.48 & 18.41 & 146.58 & 99.89 & 175.01 & 9.66 & 62.54 & 3.92 & 1.45 & 150.06 \\
\hline KOR_L16 & 107307 & 5614 & 22226 & 8692 & 27647 & 5424.34 & 15.85 & 110.4 & 96.42 & 327.81 & 7.73 & 76.49 & 5.43 & 0.65 & 132.19 \\
\hline KOR_L17 & 110148 & 6643 & 30465 & 5076 & 34809 & 5705.87 & 16.74 & 108.07 & 100.11 & 314.58 & 8.87 & 80.26 & 6.89 & 0.41 & 172.83 \\
\hline KOR_L18 & 87140 & 3581 & 26294 & 7448 & 28735 & 4969.54 & 13.77 & 97.34 & 115.32 & 165.72 & 11.87 & 76.4 & 3.34 & 0.73 & 127.3 \\
\hline KOR_L19 & 93108 & 5308 & 27652 & 11378 & 28054 & 6296.44 & 15.74 & 116.91 & 87.41 & 294.15 & 10.44 & 79.57 & 4.9 & 0.73 & 131.41 \\
\hline KOR_L20 & 106699 & 3451 & 21839 & 5173 & 18199 & 6099.58 & 17.48 & 137.19 & 107.28 & 143.77 & 6.82 & 52.38 & 3.41 & 1.21 & 162.32 \\
\hline KOR_L21 & 99038 & 3802 & 23166 & 6797 & 36458 & 6001 & 14.39 & 114.02 & 84.57 & 290.52 & 14.03 & 74.76 & 9.25 & 1.03 & 134.72 \\
\hline KOR_L22 & 98018 & 3717 & 23415 & 7984 & 34364 & 5463.49 & 15.54 & 125.87 & 88.34 & 167.69 & 11.86 & 62.13 & 8.54 & 1.24 & 140.74 \\
\hline KOR_L23 & 122918 & 3846 & 17761 & 5598 & 35099 & 6166.71 & 16.65 & 121.71 & 81.83 & 279.28 & 13.54 & 84.81 & 4.09 & 0.77 & 128.52 \\
\hline KOR_L24 & 115299 & 7604 & 20950 & 7766 & 44135 & 5209.51 & 16.32 & 107.63 & 74.43 & 314.76 & 16.87 & 141.03 & 3.62 & 0.43 & 135.33 \\
\hline KOR_L25 & 114139 & 3196 & 28554 & 5759 & 32483 & 3518.71 & 11.21 & 70.37 & 55.6 & 283.43 & 9.31 & 100.51 & 6.04 & 0.8 & 201.75 \\
\hline
\end{tabular}


Appendix A. (Continued)

\begin{tabular}{|c|c|c|c|c|c|c|c|c|c|c|c|c|c|c|c|}
\hline INAA ID & $\mathrm{AL}$ & $\mathrm{CA}$ & K & $\mathrm{NA}$ & $\mathrm{FE}$ & TI & SC & $\mathrm{v}$ & $\mathrm{CR}$ & MN & $\mathrm{CO}$ & $\mathrm{ZN}$ & AS & SB & $\mathrm{RB}$ \\
\hline KOR_L26 & 130704 & 2579 & 16341 & 5374 & 27097 & 6270.9 & 15.08 & 114.27 & 69.26 & 86.75 & 8.24 & 60.92 & 8.24 & 0.94 & 129.51 \\
\hline KOR_L27 & 98468 & 3496 & 18783 & 7979 & 22335 & 5980.18 & 16.28 & 134.19 & 95.81 & 143.1 & 7.9 & 69.75 & 4.71 & 1.3 & 138.34 \\
\hline KOR_L28 & 94059 & 3280 & 23466 & 6327 & 32213 & 5272.48 & 14.62 & 118.96 & 82.79 & 259.79 & 13.36 & 64.75 & 7.72 & 1.16 & 153.81 \\
\hline KOR_L29 & 104603 & 3717 & 22193 & 6825 & 35315 & 4727.06 & 15.39 & 102.02 & 118.64 & 251.21 & 11 & 86.05 & 4.64 & 0.75 & 148.14 \\
\hline KOR_L30 & 101087 & 2924 & 24042 & 4924 & 23734 & 5372.89 & 14.26 & 99.32 & 80.67 & 133.03 & 7.44 & 62.9 & 5.06 & 1.08 & 167.58 \\
\hline KOR_L31 & 103083 & 2639 & 25713 & 7392 & 29571 & 4761.94 & 14.07 & 112.27 & 84.82 & 133.29 & 6.92 & 57.85 & 9.84 & 1.16 & 143.94 \\
\hline KOR_L32 & 114880 & 3114 & 21003 & 8756 & 30301 & 5669.5 & 15.58 & 117.71 & 85.24 & 197.24 & 6.72 & 59.21 & 6.26 & 1.14 & 140.17 \\
\hline KOR_L33 & 102526 & 3051 & 24050 & 7302 & 32780 & 5050.92 & 15.49 & 107.73 & 96.19 & 138.92 & 7.77 & 71.5 & 10.07 & 1.14 & 151.29 \\
\hline KOR_L34 & 88582 & 3958 & 20218 & 7058 & 28649 & 5172.61 & 14.85 & 113.29 & 82.69 & 127.02 & 9.72 & 57.61 & 7.16 & 1.09 & 127.95 \\
\hline KOR_L35 & 95657 & 3887 & 20092 & 7868 & 22764 & 5505.54 & 16.48 & 128.68 & 94.48 & 135.79 & 8.17 & 53.18 & 4.38 & 1.16 & 141.62 \\
\hline KOR_L36 & 107285 & 3723 & 18968 & 7352 & 49419 & 5586.25 & 15.92 & 114.03 & 81.3 & 655.46 & 25.3 & 86.95 & 10.29 & 1.06 & 147.58 \\
\hline KOR_L37 & 94793 & 2479 & 18711 & 5905 & 28303 & 5723.75 & 15.15 & 115.81 & 85.83 & 143.65 & 9.29 & 61.23 & 6 & 1.15 & 130.2 \\
\hline KOR_L38 & 127064 & 2966 & 17823 & 5481 & 26569 & 6476.51 & 14.71 & 109.73 & 67.15 & 85.7 & 8.28 & 58.95 & 8.05 & 0.87 & 124.35 \\
\hline KOR_L39 & 109466 & 3863 & 23166 & 7620 & 31793 & 5567.47 & 17.12 & 118.31 & 107.8 & 224.97 & 10.86 & 69.05 & 6.27 & 1.14 & 150.44 \\
\hline KOR_L40 & 107150 & 2235 & 23834 & 7745 & 31340 & 4873.08 & 14.81 & 112.98 & 91.32 & 146.96 & 7.52 & 61.73 & 10.48 & 1.11 & 153.3 \\
\hline KOR_L41 & 106269 & 2867 & 22249 & 4534 & 34826 & 6655.65 & 10.26 & 93.5 & 52.64 & 158.19 & 8.1 & 76.47 & 5.58 & 0.87 & 145.78 \\
\hline KOR_L42 & 120678 & 3885 & 18756 & 4807 & 45312 & 5565.41 & 19.41 & 139.81 & 105.38 & 147.05 & 8.85 & 62.01 & 10.51 & 1.42 & 156.4 \\
\hline KOR_P01 & 91752 & 3026 & 20407 & 4886 & 28063 & 5295.4 & 11.25 & 91.76 & 73.69 & 192.77 & 8.31 & 66.92 & 7.05 & 0.78 & 103.05 \\
\hline KOR_P02 & 78727 & 2120 & 22833 & 3548 & 28161 & 3950.2 & 9.45 & 56.41 & 81.1 & 99.77 & 5.85 & 51.49 & 5.9 & 0.82 & 117.33 \\
\hline KOR_P03 & 87645 & 2793 & 24275 & 4107 & 30597 & 4515.5 & 7.84 & 70.19 & 64.56 & 264.2 & 7.18 & 75.72 & 7.69 & 0.49 & 122.3 \\
\hline KOR_P04 & 111310 & 2579 & 19040 & 3819 & 59350 & 5783.3 & 14.85 & 114.82 & 146.93 & 130.38 & 11.65 & 77.07 & 7.72 & 0.94 & 139.2 \\
\hline KOR_P05 & 81769 & 1437 & 26883 & 5212 & 23218 & 4689.2 & 10.62 & 69.17 & 70.67 & 123.25 & 6.64 & 58.32 & 5.4 & 0.8 & 134.86 \\
\hline KOR_P06 & 86256 & 3049 & 22394 & 4476 & 40723 & 5073 & 11.5 & 91.49 & 80.94 & 105.13 & 5.52 & 51.56 & 9.08 & 0.77 & 109.85 \\
\hline KOR_P07 & 89158 & 1029 & 18292 & 2265 & 37063 & 5041 & 10.4 & 80.9 & 66.48 & 132.61 & 8.45 & 56.17 & 5.5 & 0.89 & 112.71 \\
\hline
\end{tabular}


Appendix A. (Continued)

\begin{tabular}{|c|c|c|c|c|c|c|c|c|c|c|c|c|c|c|c|}
\hline INAA ID & $\mathrm{AL}$ & $\mathrm{CA}$ & K & $\mathrm{NA}$ & $\mathrm{FE}$ & TI & SC & V & $\mathrm{CR}$ & MN & $\mathrm{CO}$ & $\mathrm{ZN}$ & AS & SB & $\mathrm{RB}$ \\
\hline KOR_P08 & 84670 & 2370 & 27355 & 4595 & 19670 & 4768.3 & 9.74 & 60.13 & 77.09 & 83.5 & 8.18 & 80.99 & 1.79 & 0.78 & 115.54 \\
\hline KOR_P09 & 95844 & 3062 & 21793 & 4133 & 29646 & 4780.9 & 10.1 & 56.82 & 44.32 & 133.66 & 10.32 & 78.84 & 6.26 & 0.63 & 117.69 \\
\hline KOR_P10 & 86092 & 1715 & 16695 & 3163 & 26069 & 5024 & 9.28 & 76.5 & 66.98 & 97.96 & 6.37 & 64.55 & 7.83 & 0.71 & 83.82 \\
\hline KOR_P11 & 95014 & 1956 & 24009 & 4305 & 27487 & 4633.8 & 10.82 & 104.29 & 84.34 & 109.16 & 3.87 & 42.84 & 11.37 & 0.62 & 109.07 \\
\hline KOR_P12 & 92725 & 1881 & 16268 & 4982 & 29343 & 5446.9 & 12.72 & 100.35 & 98.41 & 125.37 & 8 & 91.68 & 6.83 & 0.75 & 120.71 \\
\hline KOR_P13 & 86441 & 2288 & 22448 & 4104 & 27759 & 4977.8 & 9.93 & 56.4 & 54.66 & 73.38 & 4.91 & 72.8 & 7.16 & 0.64 & 104.82 \\
\hline KOR_P14 & 95368 & 1394 & 21531 & 3777 & 32286 & 4818.6 & 9.98 & 79.61 & 49.83 & 96.35 & 7.42 & 69.95 & 7.03 & 0.72 & 108.07 \\
\hline KOR_P15 & 98589 & 2367 & 26775 & 6805 & 25652 & 3526.3 & 10.75 & 65.38 & 53.78 & 152.28 & 6.91 & 89.36 & 5.62 & 0.66 & 156.54 \\
\hline KOR_P16 & 104080 & 2954 & 18218 & 5602 & 50579 & 5202.1 & 15.84 & 105.03 & 105.87 & 255.19 & 16.86 & 87.6 & 8.37 & 0.67 & 125.98 \\
\hline KOR_P17 & 87995 & 1853 & 22108 & 4803 & 34666 & 4646.7 & 9.19 & 54.1 & 57.35 & 137.84 & 5.71 & 80.81 & 9.45 & 0.71 & 126.64 \\
\hline KOR_P18 & 89192 & 2438 & 24758 & 3961 & 30153 & 4519.9 & 7.77 & 66.9 & 65.86 & 238.05 & 7.13 & 87.3 & 6.34 & 0.57 & 114.89 \\
\hline KOR_P19 & 89790 & 1302 & 22520 & 3586 & 31366 & 4918.3 & 10.79 & 74.33 & 66.53 & 291.8 & 6.59 & 78.14 & 5.77 & 0.84 & 113.04 \\
\hline KOR_P20 & 85469 & 875 & 25221 & 4819 & 38056 & 4734.2 & 9.11 & 70.47 & 54.4 & 94.57 & 5.21 & 66.57 & 11.46 & 0.65 & 136.71 \\
\hline KOR_P21 & 86041 & 2545 & 19797 & 3531 & 36470 & 4354 & 8.31 & 72.12 & 51.85 & 151.34 & 4.36 & 57.04 & 8.91 & 0.82 & 121.68 \\
\hline KOR_P22 & 97609 & 1799 & 20208 & 3820 & 30444 & 5102.5 & 11.47 & 79.39 & 63.33 & 146.25 & 12.92 & 73.86 & 2.56 & 0.77 & 142.81 \\
\hline KOR_P23 & 108610 & 2061 & 19201 & 4961 & 31498 & 5884.4 & 14.21 & 97.51 & 94.21 & 106.98 & 9.24 & 155.72 & 7.5 & 0.84 & 92.91 \\
\hline KOR_P24 & 88668 & 2002 & 22361 & 4526 & 21956 & 4965 & 9.42 & 67.27 & 94.39 & 72.47 & 5.04 & 62.74 & 6.49 & 0.6 & 116.43 \\
\hline KOR_P25 & 94788 & 1176 & 16101 & 2923 & 18747 & 5061.7 & 10.34 & 82.8 & 67.44 & 111.4 & 5.46 & 50.73 & 7.77 & 0.71 & 100.89 \\
\hline KOR_P26 & 83347 & 2263 & 21200 & 3751 & 32703 & 4959.4 & 9.63 & 82.03 & 80.35 & 74.16 & 4.13 & 41.84 & 8.27 & 0.46 & 110.71 \\
\hline KOR_P27 & 98561 & 2063 & 19419 & 3539 & 30808 & 5244.9 & 11.1 & 86.45 & 68.35 & 133.38 & 9.99 & 81.48 & 1.45 & 0.83 & 143.38 \\
\hline KOR_P28 & 107050 & 3169 & 19233 & 7854 & 32292 & 5953.7 & 15.54 & 124.78 & 97.04 & 101.08 & 8.55 & 61.08 & 9.12 & 0.97 & 112.49 \\
\hline KOR_P29 & 84858 & 2159 & 16444 & 4154 & 45760 & 6124.9 & 11.85 & 91.7 & 80.57 & 240.46 & 8.08 & 69.89 & 11.76 & 1 & 116.56 \\
\hline KOR_P30 & 100110 & 2338 & 20128 & 3618 & 29577 & 4937.8 & 10.76 & 85.14 & 64.87 & 131.56 & 9.28 & 63.9 & 1.26 & 0.73 & 141.25 \\
\hline $\begin{array}{l}\text { Normalization } \\
\text { Standard }\end{array}$ & 101140 & 7949 & 19519 & 8148 & 38656 & 6802.4 & 15.59 & 118.25 & 101.22 & 271.88 & 12.05 & 84.21 & 7.22 & 0.81 & 116.35 \\
\hline
\end{tabular}


Appendix B. INAA Data, Cesium through Uranium

\begin{tabular}{|c|c|c|c|c|c|c|c|c|c|c|c|c|c|c|c|}
\hline INAA ID & CS & BA & LA & $\mathrm{CE}$ & ND & SM & EU & TB & DY & $\mathrm{YB}$ & LU & $\mathrm{HF}$ & TA & $\mathrm{TH}$ & $\mathrm{U}$ \\
\hline KOR_L01 & 11.25 & 896.28 & 73.91 & 145.17 & 54.34 & 10.44 & 1.88 & 1.13 & 6.55 & 2.94 & 0.4 & 9.78 & 1.48 & 21.39 & 5.37 \\
\hline KOR_L02 & 7.93 & 1276.87 & 66.71 & 127.31 & 58.31 & 8.28 & 1.63 & 1.04 & 5.71 & 2.7 & 0.42 & 7.1 & 1.75 & 21.64 & 4.99 \\
\hline KOR_L03 & 10.98 & 712.06 & 48.61 & 98.15 & 37.04 & 8 & 1.46 & 1.06 & 6.4 & 3.17 & 0.43 & 7.17 & 1.36 & 17.34 & 4.32 \\
\hline KOR_L04 & 10.87 & 760.15 & 52.7 & 104.08 & 50.62 & 7.58 & 1.64 & 0.93 & 5.53 & 2.37 & 0.37 & 7.1 & 1.41 & 22.07 & 4.88 \\
\hline KOR_L05 & 10.66 & 680.3 & 63.6 & 122.76 & 59.15 & 10.68 & 2.13 & 1.39 & 8.68 & 3.98 & 0.54 & 6.38 & 1.37 & 18.35 & 4.95 \\
\hline KOR_L06 & 8.2 & 673.37 & 60.44 & 116.61 & 55.82 & 9.67 & 1.7 & 1.27 & 7.24 & 3.43 & 0.45 & 7.89 & 1.34 & 19.98 & 3.94 \\
\hline KOR_L07 & 9.15 & 677.71 & 46.2 & 94.83 & 41.19 & 7.38 & 1.47 & 0.95 & 6.07 & 3.07 & 0.42 & 7.13 & 1.46 & 17.86 & 4.82 \\
\hline KOR_L08 & 9.36 & 788.45 & 53.89 & 109.93 & 35.62 & 8.94 & 1.71 & 1.12 & 7.18 & 3.52 & 0.47 & 7.53 & 1.53 & 19.56 & 4.2 \\
\hline KOR_L09 & 9.29 & 656.95 & 47.17 & 98.84 & 41.43 & 7.31 & 1.27 & 1.01 & 5.02 & 2.44 & 0.34 & 8.2 & 1.5 & 18.51 & 3.97 \\
\hline KOR_L10 & 10.45 & 645.9 & 45.52 & 95.4 & 42.76 & 8.13 & 1.56 & 1.02 & 6.72 & 3.27 & 0.46 & 8.68 & 1.52 & 18.91 & 5.37 \\
\hline KOR_L11 & 7.08 & 1289.33 & 56.26 & 107.37 & 43.92 & 9.1 & 1.66 & 1.11 & 7 & 3.25 & 0.52 & 8.24 & 1.5 & 18.76 & 6.67 \\
\hline KOR_L12 & 8.23 & 721.59 & 60.19 & 116.07 & 39.48 & 9.7 & 1.72 & 1.03 & 6.54 & 3.5 & 0.54 & 6.46 & 1.18 & 19.71 & 3.95 \\
\hline KOR_L13 & 6.72 & 1426.27 & 57.53 & 114.91 & 45.7 & 8.68 & 1.78 & 1.01 & 6.38 & 2.81 & 0.44 & 8.31 & 1.29 & 18.87 & 6.46 \\
\hline KOR_L14 & 7.92 & 763.21 & 51.94 & 107.54 & 34.64 & 8.25 & 1.58 & 0.96 & 6.2 & 3.06 & 0.47 & 7.97 & 1.23 & 16.98 & 3.51 \\
\hline KOR_L15 & 12.77 & 572.25 & 52.34 & 106.87 & 41.82 & 8.92 & 1.72 & 1.1 & 6.82 & 3.4 & 0.48 & 5.79 & 1.45 & 19.7 & 5.08 \\
\hline KOR_L16 & 8.25 & 1284.73 & 47.64 & 97.12 & 34.55 & 7.97 & 1.59 & 1.07 & 6.7 & 3.26 & 0.58 & 5.88 & 1.39 & 16.13 & 4.14 \\
\hline KOR_L17 & 7.44 & 1240.22 & 64.53 & 119.24 & 54.88 & 9.58 & 1.56 & 1.07 & 6.04 & 2.71 & 0.41 & 5.5 & 1.26 & 28.12 & 3.72 \\
\hline KOR_L18 & 5.95 & 979.29 & 49.91 & 99.13 & 38.89 & 7.66 & 1.42 & 1.05 & 6.18 & 3.41 & 0.5 & 7.7 & 1.3 & 17.16 & 3.94 \\
\hline KOR_L19 & 7.39 & 884.79 & 48.45 & 95.72 & 34.48 & 7.2 & 1.38 & 1.06 & 5.43 & 2.99 & 0.45 & 9.72 & 1.53 & 18.2 & 4.52 \\
\hline KOR_L20 & 11.81 & 634.66 & 51.21 & 108.86 & 35.36 & 8.44 & 1.7 & 1.19 & 7.03 & 3.31 & 0.56 & 7.98 & 1.7 & 19.05 & 5.24 \\
\hline KOR_L21 & 10.22 & 751.02 & 49.8 & 100.58 & 29.59 & 8.05 & 1.58 & 1.12 & 6.2 & 3.3 & 0.45 & 8.45 & 1.49 & 17.96 & 4.67 \\
\hline KOR_L22 & 10.95 & 651.76 & 45.67 & 97.3 & 28.61 & 7.75 & 1.6 & 0.99 & 6.17 & 3.19 & 0.43 & 7.74 & 1.46 & 17.22 & 4.63 \\
\hline KOR_L23 & 11.86 & 654.29 & 64.56 & 124.83 & 40.16 & 9.51 & 2.18 & 1.26 & 7.03 & 3.21 & 0.45 & 6.65 & 1.77 & 17.71 & 7.11 \\
\hline KOR_L24 & 7.84 & 735.82 & 65.83 & 132.33 & 43.33 & 9.18 & 1.93 & 1.17 & 6.12 & 3.06 & 0.44 & 8.12 & 1.24 & 19.73 & 6.26 \\
\hline KOR_L25 & 9.01 & 711.46 & 51.4 & 100.36 & 44.49 & 8.52 & 1.34 & 0.89 & 4.77 & 2.65 & 0.31 & 7.29 & 1.99 & 19.87 & 6.01 \\
\hline
\end{tabular}


Appendix B. (Continued)

\begin{tabular}{|c|c|c|c|c|c|c|c|c|c|c|c|c|c|c|c|}
\hline INAA ID & CS & $\mathrm{BA}$ & LA & $\mathrm{CE}$ & ND & SM & EU & $\mathrm{TB}$ & DY & YB & LU & $\mathrm{HF}$ & TA & $\mathrm{TH}$ & U \\
\hline KOR_L26 & 10.48 & 500.45 & 67.73 & 141.68 & 61.84 & 10.55 & 2.14 & 1.25 & 7.21 & 3.21 & 0.37 & 5.65 & 1.47 & 21.85 & 5.07 \\
\hline KOR_L27 & 10.5 & 621.19 & 72.14 & 137.62 & 56.58 & 10.65 & 2.12 & 1.39 & 8.42 & 4.18 & 0.61 & 7.89 & 2.16 & 18.39 & 4.97 \\
\hline KOR_L28 & 9.94 & 686.3 & 54.61 & 102.21 & 48.65 & 8.64 & 1.54 & 1.05 & 6.22 & 3.5 & 0.55 & 8.22 & 1.49 & 17.62 & 4.99 \\
\hline KOR_L29 & 8.35 & 632.48 & 47.37 & 95.33 & 44.84 & 7.73 & 1.55 & 0.92 & 5.51 & 3.01 & 0.43 & 6.92 & 1.12 & 16.16 & 3.82 \\
\hline KOR_L30 & 10.77 & 707.94 & 53.07 & 106.58 & 34.6 & 8.41 & 1.62 & 0.92 & 5.61 & 3.01 & 0.46 & 8.21 & 1.55 & 18.91 & 4.66 \\
\hline KOR_L31 & 9.82 & 728.53 & 56.05 & 98.35 & 41.11 & 9.89 & 1.86 & 1.09 & 6.38 & 3.29 & 0.48 & 6.62 & 1.26 & 18.88 & 4.31 \\
\hline KOR_L32 & 10.75 & 615.45 & 56.76 & 116.86 & 48.52 & 9.35 & 1.76 & 1.07 & 6.19 & 3.32 & 0.4 & 8.6 & 1.44 & 20.55 & 5.24 \\
\hline KOR_L33 & 10.82 & 699.44 & 54.06 & 106.91 & 61.92 & 9.61 & 1.98 & 1.22 & 6.31 & 3.18 & 0.45 & 6.99 & 1.33 & 20.48 & 4.1 \\
\hline KOR_L34 & 10.03 & 567.84 & 61.42 & 116.41 & 51.69 & 9.62 & 1.8 & 1.12 & 6.92 & 3.8 & 0.56 & 8.17 & 1.4 & 16.89 & 4.91 \\
\hline KOR_L35 & 10.64 & 591.96 & 72.46 & 139.32 & 52.82 & 10.91 & 2.12 & 1.41 & 8.01 & 4.04 & 0.57 & 7.5 & 1.46 & 18.24 & 4.69 \\
\hline KOR_L36 & 10.26 & 597.58 & 62.62 & 139.43 & 54.64 & 9.48 & 1.71 & 1.07 & 5.92 & 3.29 & 0.52 & 7.57 & 1.8 & 20.85 & 6.19 \\
\hline KOR_L37 & 10.09 & 694.55 & 63.62 & 117.69 & 58.19 & 10.22 & 1.92 & 1.25 & 7.22 & 3.76 & 0.55 & 8.45 & 1.68 & 17.61 & 5.28 \\
\hline KOR_L38 & 10.75 & 505.34 & 68.75 & 136.12 & 54.91 & 10.56 & 2.14 & 1.14 & 6.7 & 3.28 & 0.47 & 5.79 & 1.44 & 19.74 & 5.35 \\
\hline KOR_L39 & 11.37 & 658 & 59.91 & 120.15 & 54.32 & 9.86 & 1.77 & 1.31 & 7.42 & 3.63 & 0.51 & 8 & 1.65 & 21.08 & 4.82 \\
\hline KOR_L40 & 10.33 & 736.37 & 50.36 & 94.29 & 49.25 & 9.2 & 1.89 & 1.2 & 6.67 & 3.23 & 0.44 & 6.76 & 1.38 & 17.92 & 4.19 \\
\hline KOR_L41 & 8.79 & 518.94 & 63.14 & 113.41 & 56.56 & 8.17 & 1.51 & 0.94 & 4.42 & 2.28 & 0.32 & 9.86 & 1.68 & 20.73 & 5.45 \\
\hline KOR_L42 & 13.32 & 453.33 & 49.7 & 104.42 & 40.63 & 8.71 & 1.65 & 1.13 & 5.97 & 3.34 & 0.47 & 5.91 & 1.45 & 22.14 & 5.32 \\
\hline KOR_P01 & 5.15 & 808.86 & 37.91 & 76.23 & 24.83 & 6.1 & 1.18 & 0.8 & 4.32 & 2.46 & 0.33 & 10.33 & 1.45 & 14.41 & 4.55 \\
\hline KOR_P02 & 5.29 & 869.65 & 34.21 & 68.53 & 36.46 & 5.31 & 1.1 & 0.61 & 3.44 & 1.93 & 0.25 & 8.97 & 1.31 & 13.65 & 3.63 \\
\hline KOR_P03 & 5.06 & 1292.2 & 37.04 & 75.31 & 25.42 & 4.7 & 1.04 & 0.44 & 2.79 & 1.71 & 0.23 & 8 & 0.99 & 12.53 & 3.32 \\
\hline KOR_P04 & 8.98 & 517.09 & 45.73 & 86.58 & 44.04 & 6.44 & 1.21 & 0.81 & 4.73 & 2.62 & 0.3 & 8.09 & 1.47 & 18.67 & 4.66 \\
\hline KOR_P05 & 5.96 & 1057 & 35.65 & 73 & 31.06 & 5.58 & 1.07 & 0.63 & 3.78 & 2.11 & 0.26 & 7.27 & 1.42 & 16.44 & 3.71 \\
\hline KOR_P06 & 4.33 & 882.35 & 29.49 & 64.51 & 33.25 & 5.03 & 1.06 & 0.73 & 3.45 & 2.28 & 0.26 & 8.84 & 1.52 & 15.36 & 4.36 \\
\hline KOR_P07 & 6.6 & 653.03 & 27.73 & 53.77 & 20.49 & 4.11 & 0.72 & 0.53 & 2.78 & 1.78 & 0.23 & 8 & 1.72 & 14.22 & 3.93 \\
\hline
\end{tabular}


Appendix B. (Continued)

\begin{tabular}{|c|c|c|c|c|c|c|c|c|c|c|c|c|c|c|c|}
\hline INAA ID & $\mathrm{CS}$ & $\mathrm{BA}$ & LA & $\mathrm{CE}$ & ND & SM & EU & $\mathrm{TB}$ & DY & $\mathrm{YB}$ & LU & $\mathrm{HF}$ & $\mathrm{TA}$ & $\mathrm{TH}$ & $\mathrm{U}$ \\
\hline KOR_P08 & 5.43 & 894.73 & 32.83 & 66.36 & 35.24 & 4.69 & 1.12 & 0.56 & 3.24 & 1.96 & 0.25 & 8.58 & 1.34 & 15.04 & 3.44 \\
\hline KOR_P09 & 6.24 & 876.66 & 38.69 & 99.61 & 37.38 & 6.15 & 1.28 & 0.75 & 3.76 & 2.22 & 0.29 & 9.68 & 1.71 & 16.28 & 4.87 \\
\hline KOR_P10 & 2.56 & 610.32 & 40.3 & 81.06 & 34.54 & 5.88 & 1.08 & 0.66 & 3.96 & 2.22 & 0.3 & 9.7 & 1.72 & 17.3 & 4.38 \\
\hline KOR_P11 & 4.8 & 800.39 & 42.25 & 78.73 & 44.32 & 6.54 & 1.24 & 0.73 & 4.23 & 2.48 & 0.29 & 7.99 & 1.37 & 17.42 & 4.53 \\
\hline KOR_P12 & 7.91 & 820.22 & 42.4 & 83.03 & 35.74 & 6.23 & 1.23 & 0.76 & 4.25 & 2.32 & 0.32 & 8.02 & 1.44 & 16.91 & 3.92 \\
\hline KOR_P13 & 5.18 & 817.54 & 26.47 & 60.45 & 23.23 & 4.46 & 0.95 & 0.53 & 3.14 & 1.9 & 0.2 & 7.42 & 1.82 & 15.24 & 4.61 \\
\hline KOR_P14 & 5.31 & 895.98 & 27.71 & 57.84 & 21.07 & 4.12 & 0.89 & 0.57 & 3.26 & 1.77 & 0.24 & 7.79 & 1.45 & 16.55 & 3.86 \\
\hline KOR_P15 & 6.81 & 783.48 & 40.67 & 76.78 & 33.97 & 6.03 & 1.12 & 0.76 & 5.17 & 2.69 & 0.37 & 6.23 & 1.42 & 16.67 & 4.46 \\
\hline KOR_P16 & 7.58 & 645.98 & 51.77 & 101.71 & 45.9 & 7.87 & 1.78 & 0.97 & 5.11 & 2.98 & 0.37 & 7.6 & 1.44 & 18.09 & 4.36 \\
\hline KOR_P17 & 5.44 & 1014.8 & 32.91 & 64.39 & 28.5 & 4.28 & 0.94 & 0.63 & 2.94 & 1.65 & 0.26 & 7.8 & 1.2 & 12.26 & 2.69 \\
\hline KOR_P18 & 5.19 & 1272.8 & 40.05 & 78.46 & 19.36 & 4.83 & 1.08 & 0.51 & 3.02 & 1.75 & 0.21 & 7.74 & 1.03 & 11.64 & 3.27 \\
\hline KOR_P19 & 5.64 & 1164.6 & 46.94 & 84.12 & 49.01 & 6.69 & 1.15 & 0.73 & 4.43 & 2.22 & 0.35 & 8.3 & 1.45 & 18.71 & 4.38 \\
\hline KOR_P20 & 5.16 & 945.31 & 49.65 & 94.41 & 41.5 & 6.88 & 1.23 & 0.84 & 4.7 & 2.37 & 0.3 & 8.46 & 1.69 & 17.84 & 3.47 \\
\hline KOR_P21 & 6.58 & 718.17 & 47.66 & 81.52 & 32.38 & 4.82 & 0.86 & 0.45 & 3.15 & 1.95 & 0.26 & 8.23 & 1.45 & 15.64 & 3.26 \\
\hline KOR_P22 & 8.49 & 713.75 & 58.13 & 131.67 & 47.41 & 8.12 & 1.55 & 0.93 & 5.06 & 2.68 & 0.33 & 9.92 & 1.65 & 19.22 & 4.5 \\
\hline KOR_P23 & 3.12 & 625.46 & 38.88 & 78.04 & 34.98 & 6.36 & 1.15 & 0.95 & 4.95 & 3.08 & 0.41 & 10.88 & 1.67 & 21.02 & 4.71 \\
\hline KOR_P24 & 6.16 & 970.66 & 33.67 & 67.56 & 26.05 & 4.8 & 1.02 & 0.62 & 3.31 & 1.84 & 0.24 & 8.89 & 1.32 & 15.19 & 3.25 \\
\hline KOR_P25 & 5.4 & 877.83 & 36.67 & 88.06 & 27.04 & 5.28 & 0.95 & 0.6 & 3.64 & 2.36 & 0.34 & 8.66 & 1.1 & 16.74 & 3.95 \\
\hline KOR_P26 & 4.62 & 766.48 & 26.62 & 53.86 & 21.05 & 4.36 & 0.89 & 0.49 & 2.91 & 1.98 & 0.28 & 8.37 & 1.36 & 12.45 & 3.94 \\
\hline KOR_P27 & 8.39 & 543.19 & 56.8 & 117.59 & 42.59 & 7.91 & 1.5 & 0.9 & 4.69 & 2.79 & 0.39 & 8.37 & 1.54 & 19.44 & 3.98 \\
\hline KOR_P28 & 6.39 & 639.46 & 47.24 & 97.48 & 38.88 & 7.62 & 1.38 & 1.09 & 6.05 & 3.29 & 0.48 & 7.15 & 1.53 & 18.88 & 4.37 \\
\hline KOR_P29 & 6.62 & 723.58 & 30.75 & 60.68 & 19.15 & 4.6 & 0.89 & 0.65 & 3.12 & 2.18 & 0.35 & 8.36 & 1.4 & 14.65 & 4.02 \\
\hline KOR_P30 & 8.72 & 640.71 & 56.61 & 99.27 & 37.84 & 7.92 & 1.47 & 0.86 & 4.71 & 2.71 & 0.38 & 7.95 & 1.54 & 19.09 & 4.19 \\
\hline $\begin{array}{l}\text { Normalization } \\
\text { Standard }\end{array}$ & 7.07 & 781.27 & 48.39 & 94.60 & 40.20 & 7.76 & 1.66 & 0.96 & 5.53 & 2.92 & 0.43 & 7.61 & 1.70 & 17.32 & 4.21 \\
\hline
\end{tabular}




\section{ACKNOWLEDGMENTS}

We would like to extend our sincere gratitude to Kwon Oh Young of Seoul National University for providing ceramic samples for this analysis, and to Seong Jeong Yong of Chungbuk National University for his assistance in an earlier phase of this project. This work was carried out with the very great help of Habeom Kim, Hyunsoo Lee, and Stephen Dueppen at the University of Oregon, Leah Minc at Oregon State University. This project is funded by the Academy of Korean Studies KSPS Laboratory Grant \#20150273.

\section{REFERENCES CITED}

Alden, John R., And Leah Minc

2016 Itinerant potters and the transmission of ceramic technologies and styles during the ProtoElamite Period in Iran. Journal of Archaeological Science: Reports 7:863-876.

Arnold, Dean E.

2000 Does the standardization of ceramic pastes really mean specialization? Journal of Archaeological Method and Theory 7(4):333-375.

Arnold, Dean E., Hector NefF, and Ronald L. Bishop

1991 Compositional analysis and "sources" of pottery: An ethnoarcheological approach. American Anthropologist 93(1):70-90.

BEST, JONATHAN W.

2006 A History of the Early Korean Kingdom of Paekche: Together with an Annotated Translation of the Paekche Annals of the Samguk Sagi. Cambridge, MA: Harvard University Press.

Blackman, M. James, Gil J. Stein, and Pamela B. Vandiver

1993 The standardization hypothesis and ceramic mass production: Technological, compositional, and metric indexes of craft specialization at Tell Leilan, Syria. American Antiquity 58(1):60-80.

Blanton, Richard E., and Lane F. Fargher

2008 Collective Action in the Formation of Pre-Modern States. Fundamental Issues in Archaeology. New York: Springer.

2011 The collective logic of pre-modern cities. World Archaeology 43(3):505-522.

2016 How Humans Cooperate: Confronting the Challenge of Collective Action. Boulder: University Press of Colorado.

Brumfiel, Elizabeth M., and Timothy K. Earle

1987 Specialization, Exchange, and Complex Societies. Cambridge, UK: Cambridge University Press.

Byington, Mark E.

2009 The Samhan Period in Korean History. Cambridge, MA: Harvard University Press.

Carballo, David M., and Gary M. Feinman

2016 Cooperation, collective action, and the archeology of large-scale societies. Evolutionary Anthropology: Issues, News, and Reviews 25(6):288-296.

Chilton, Elizabeth S.

1999 One size fits all: Typology and alternatives for ceramic research, in Material Meanings: 44-60, ed. Elizabeth S. Chilton. Salt Lake City: University of Utah Press.

Cho, DAEYoun

2006 Crafting the State: Analytical Approaches to Ceramic Technology and Exchange from the Bronze Age to Paekche Periods in Korea. Ph.D. thesis. University of Sheffield.

Choi, Jongtaik

2008 The development of the pottery technologies of the Korean peninsula and their relationship to neighboring regions, in Reconsidering Early Korean History through Archaeology, Vol. 1: 157-198, ed. Mark E. Byington. Cambridge, MA: Harvard University Press.

Chough, Sung Kwun

2013 Geology and Sedimentology of the Korean Peninsula. New York: Elsevier.

Costin, Cathy Lynne

1991 Craft specialization: Issues in defining, documenting, and explaining the organization of production. Archaeological Method and Theory 31-56. 
1998 Introduction: Craft and social identity, in Craft and Social Identity: 3-16, ed. Cathy Lynne Costin and Rita P. Wright. Arlington, VA: American Anthropological Association.

2001 Craft production systems, in Archaeology at the Millennium: 273-327, ed. Gary M. Feinman and T. Douglas Price. New York: Kluwer Academic/Plenum Publishers.

2007 Thinking about production: Phenomenological classification and lexical semantics, in Rethinking Craft Specialization in Complex Societies: 143-162, ed. Zachary X. Hruby and Rowan K. Flad. Arlington, VA: American Anthropological Association.

DeMarrais, Elizabeth

2007 Settings and symbols: Assessing complexity in the Pre-Hispanic Andes, in Socialising Complexity: 118-139, ed. Stephanie Wynne-Jones and Sheila Kohring. Oxford: Oxbow Books.

DeMarrais, Elizabeth, Luis Jaime Castillo, and Timothy Earle

1996 Ideology, materialization, and power strategies. Current Anthropology 37(1):15-31.

Dong, Shumen, Yueqiao Zhang, Fugin Zhang, Jianjun Cui, Xuanhua Chen, Shuanhong Zhang, Laicheng Miao, Jianhua Li, Wei Shi, Zhenhong Li, Shiqi Huang, and Hailong Li

2015 Late Jurassic-Early Cretaceous continental convergence and intracontinental orogenesis in East Asia: A synthesis of the Yanshan revolution. Journal of Asian Earth Sciences 114:750-770.

Dueppen, Stephen A.

2015 Expressing difference: Inequality and house-based potting in a first-millennium AD community (Burkina Faso, West Africa). Cambridge Archaeological Journal 25(1):17-43.

Flad, Rowan K., and Zachary X. Hruby

2007 'Specialized' production in archaeological contexts: Rethinking specialization, the social value of products, and the practice of production, in Rethinking Craft Specialization in Complex Societies: 1-19, ed. Zachary X. Hruby and Rowan K. Flad. Arlington, VA: American Anthropological Association.

Gopnik, Hilary, Clemens Reichel, Leah Minc, and Rasha Elendari

2016 A view from the east: The Godin VI Oval and the Uruk Sphere. Journal of Archaeological Science: Reports 7(June):835-848.

Gosselain, Olivier P.

1998 Social and technical identity in a clay crystal ball, in The Archaeology of Social Boundaries: 78-106, ed. Miriam T. Stark. Washington, D.C.: Smithsonian Institution Press.

2000 Materializing identities: An African perspective. Journal of Archaeological Method and Theory 7(3):187-217.

Grave, P., M. Stark, D. Ea, L. Kealhofer, B. S. Tan, and T. Tin

2017 Differentiating Khmer stoneware production: An NAA pilot study from Siem Reap Province, Cambodia. Archaeometry 59(1):13-24.

HAN’GUK ChIJIL ChawŎN YŎN'GUWŎN 한국지질자원연구원 [KOREAn INSTITUTE OF GEOSCIENCE AND Mineral Resources]

2016 Geological Map: 50,000:1. 한국지질자원연구원 지질정보시스템 [Korean Institute of Geoscience and Mineral Resources Geological Information System](website), accessed 18 November 2016, at mgeo.kigam.re.kr/.

Hannam Taehakkyo Chungang Pangmulgwan 韓南大學校中央博物館 [Hannam University Central Museum]

2006 Chinch'ŏn Samnyong-ni-Sansu-ri t'ogi yojigun 鎭川三龍里-山水里土器 窯址群 [Pottery Kiln Sites at Samryong-ri and Sansu-ri, Jincheon-gun]. Hannam Taehakkyo Chungang Pangmulgwan ch'ongsó 24 韓南大學校 中央博物館叢書 24 [Archaeological Research Report 24]. Taejŏn: Hannam Taehakkyo Chungang Pangmulgwan.

Hansŏng PaEkche PAngmulgwan 한성백제박물관 And Hansin TAehakkyo Pangmulgwan 한신대학교박물관 [SEOUl BAekJE Museum AND Hanshin University Museum]

2011 P'ungnap T'osŏng XII: Kyŏngdang chigu 196-ho yugu e taehan pogo 風納土城 XII: 慶堂地區 196 號遺構에 대한 報告 [Pungnap Earthen Wall XII: Excavation Report of the Site No. 196 at Gyeongdang District]. Hansin Taehakkyo Pangmulgwan ch'ongsŏ che 37-ch'aek 한신 대학교 박물관총서 제 37책 [Hanshin University Museum Research Series 37]. Osan: Hansin Taehakkyo Pangmulgwan. 
2015 P'ungnap T'osŏng XVII: Kyŏngdang chigu 206-ho yugu e taehan pogo 風納土城 XVII: 慶堂地區 206號遺構에 대한 報告 [Pungnap Earthen Wall XVII: Excavation Report of the Site No. 206 at Gyeongdang District]. Hansin Taehakkyo Pangmulgwan ch'ongsŏ che 41-ch'aek 한신대학교 박물관총서 제 41 책 [Hanshin University Museum Research Series 41]. Osan: Hansin Taehakkyo Pangmulgwan.

HAYDEN, BRIAN

1998 Practical and prestige technologies: The evolution of material systems. Journal of Archaeological Method and Theory 5(1):1-55.

Helms, Mary W.

1993 Craft and the Kingly Ideal. Austin: University of Texas Press.

Hirth, Kenneth G.

1996 Political economy and archaeology: Perspectives on exchange and production. Journal of Archaeological Research 4(3):203-239.

IM YŎNGJIN 임영진 [YIM YOUNGJIN]

2014 Chŏnnam chiyŏk Mahan cheguk ŭi sahoe sŏnggyŏk kwa Paekche 전남지역 마한 제국의 사회 성격과 백제 [Social characteristics of the Mahan statelets in the Jeonnam region and their relationship with Baekje]. Paekche hakpo 百濟學報 11:5-32.

Junker, Laura LeE

1999 Raiding, Trading, and Feasting: The Political Economy of Philippine Chiefdoms. Honolulu: University of Hawai'i Press.

Kim, Minkoo, Heung-Nam Shin, Jinhee Kim, Kyeong-jung Roh, Ara Ryu, Haesun Won, Juho Kim, Semi Oh, Hyeongsin Noh, and Sumin Kim

2016 The ins and the outs: Foodways, feasts, and social differentiation in the Paekche Kingdom, Korea. Journal of Anthropological Archaeology 43:128-139.

KIM SǓNGOK 김승옥 [KIM SEUNG-OG]

2014 Chŏnnam chiyŏk Mahan cheguk ŭi sahoe sŏnggyŏk kwa Paekche; ch'wirak ŭro pon Chŏnnam chiyŏk Mahan sahoe ŭi kujo wa sŏnggyŏk 전남지역 마한 제국의 사회 성격과 백제; 취락으로 본 전남지역 마한 사회의 구조와 성격 [Structure and characteristics of Chŏnnam region's Mahan society through an analysis of settlements]. Paekche hakpo 百濟學 報 11:33-72.

KIM WŎNYONG 金元龍 [KIM WON-YONG], Im HyOJAE 任孝宰 [Im HyO-JAE], AND IM YŎNGJIN 林永珍 [YIM YOUNG-JIN]

1989 Sókch'on-dong 1,2-hobun 石村洞 1·2號墳 [Stone-mounded Tomb No. 1 and No. 2 at Seokchon-dong]. Seoul Taehakkyo kogo illyuhak ch'onggan 14 서울大學校 考古人類學叢 刊 14 [Archaeological and Anthropological Articles of Seoul National University, vol. 14]. Seoul: Seoul Taehakkyo Pangmulgwan.

Kohring, Sheila, Carlos P. Odriozola, and Victor M. Hurtado

2007 Materializing 'complex' relationships: Technology production and consumption in a Copper Age community, in Socialising Complexity: 100-117, ed. Stephanie Wynne-Jones and Sheila Kohring. Oxford: Oxbow Books.

KRISTIANSEN, KRISTIAN

2007 The rules of the game: Decentralized complexity and power, in Socialising Complexity: 60-75, ed. Stephanie Wynne-Jones and Sheila Kohring. Oxford: Oxbow Books.

KwŎN OYǑNG 권오영 [KwON OH YOUNG]

2008 The influence of recent archaeological discoveries on the research of Paekche history, in Early Korea 1: Reconsidering Early Korean History through Archaeology: 65-112, ed. Mark E. Byington. Cambridge, MA: Harvard UP.

2011 Hansŏng Paekche ŭi siganjŏk sanghan kwa hahan 한성백제(漢城百濟)의 시간적(時間的) 상한(上限)과 하한(下限) [Chronological study of the Hansŏng period of Paekche]. Paekche yon' $g u$ 百濟研究 53:131-157.

2015 Mahan pun'gumyo ŭi ch'urhyŏn kwajŏng kwa choyŏng chiptan 마한 분구묘의 출현 과정과 조영집단 [The emergence of Mound Tomb in Mahan region and its builders]. Paekche hakpo 百濟學報 14:37-58.

KwŎN OYŎNG 권오영 [KwON OH YOUNG] AND KIM CHANGSǑK 김장석

2008 Hansŏng yangsik t'ogi ŭi yut'ongmang punsǒk 한성양식 토기의 유통망 분석 [Analysis of the distribution of pottery forms in the Hansŏng period], in Paekche saengsan kisul ŭi paldal kwa 
yut'ong ch'egye hwaktae ŭi chŏngch'i sahoejŏk hamŭi 백제 생산기술의 발달과 유통체계 확대의 정치사회석 함의 [Political and Social Implications of the Development and Expansion of the Paekche Production and Distribution System]: 99-144, ed. Hansin Taehakkyo Haksulwŏn 한신대학교 학술원. Osan: Hanshin Taehakkyo Ch'ulp'anbu.

LeChTMAN, HeAther

1977 Style in technology: Some early thoughts, in Material Culture: 3-20, ed. Heather Lechtman and Robert S. Merrill. St. Paul, MN: West Publishing Co.

LeE, DenNis

2014 Keyhole-Shaped Tombs and Unspoken Frontiers: Exploring the Borderlands of Early KoreanJapanese Relations in the 5th-6th Centuries. Ph.D. diss. University of California, Los Angeles.

Lemonnier, Pierre

1992 Elements for an Anthropology of Technology. Ann Arbor, MI: Museum of Anthropology, University of Michigan.

1993 Technological Choices: Transformation in Material Cultures since the Neolithic. London: Routledge.

McIntosh, Susan KeECH

1999 Modeling political organization in large-scale settlement clusters: A case study from the inland Niger delta, in Beyond Chiefdoms: 66-79, ed. Susan Keech McIntosh. Cambridge, UK: Cambridge University Press.

Michelaki, Kostalena, Gregory V. Braun, and Ronald G. V. Hancock

2015 Local clay sources as histories of human-landscape interactions: A ceramic taskscape perspective. Journal of Archaeological Method and Theory 22(3):783-827.

Michelaki, Kostalena, Ronald G. V. Hancock, and Gregory V. Braun

2012 Using provenance data to assess archaeological landscapes: An example from Calabria, Italy. Journal of Archaeological Science 39(2):234-246.

Minc, Leah D.

2006 Monitoring regional market systems in prehistory: Models, methods, and metrics. Journal of Anthropological Archaeology 25(1):82-116.

2009 Style and substance: Evidence for regionalism within the Aztec Market System. Latin American Antiquity 20(2):343-374.

2016 Trace-element analyses of Uruk ceramics: Establishing a database to track interregional exchange. Journal of Archaeological Science: Reports 7(June):798-807.

Minc, Leah D., R. Jason Sherman, Christina Elson, Marcus Winter, Elsa M. Redmond, and Charles S. Spencer

2016 Ceramic provenance and the regional organization of pottery production during the later Formative periods in the Valley of Oaxaca, Mexico: Results of trace-element and mineralogical analyses. Journal of Archaeological Science: Reports 8:28-46.

Monroe, J. Cameron

2010 Power by design: Architecture and politics in Precolonial Dahomey. Journal of Social Archaeology 10(3):367-397.

2013 Power and agency in precolonial African states. Annual Review of Anthropology 42(1):17-35.

NAM SANGWŎN 남상원 [NAM SANGWON]

2013 Chejak kisul ŭl t'onghae pon Paekche hŭksaek mayŏn t'ogi ŭi ŭimi 제작 기술을 통해 본 백제 흑색마연토기의 의미 [The meaning of Black Burnished Pottery in Paekche as a production technology]. Han'guk kogo hakpo 韓國考古學報 89:94-137.

NefF, Hector

2002 Quantitative techniques for analyzing ceramic compositional data, in Ceramic Production and Circulation in the Greater Southwest: Source Determination by INAA and Complementary Mineralogical Investigations: 15-36, ed. D. M. Glowacki and H. Neff. Monograph 44. Los Angeles: The Cotsen Institute.

Neff, Hector, Ronald L. Bishop, and Edward V. Sayre

1988 A simulation approach to the problem of tempering in compositional studies of archaeological ceramics. Journal of Archaeological Science 15:159-172.

1989 More observations on the problem of tempering in compositional studies of archaeological ceramics. Journal of Archaeological Science 16:57-69. 
Pailes, Matthew C.

2016 Exchange economies of Late Prehistoric Eastern Sonora, Mexico: A re-evaluation based on provenance data analyses. Journal of Field Archaeology 41(5):587-602.

PAK ChungGyun 朴重均 [PARK JUnGKyun]

2015 Mihoch'ŏn yuyŏk ŭi Mahan esŏ Paekche ro ŭi chŏnhwan kwa chaeji seryŏk ŭi chonjae yangt'ae 미호천유역의 마한에서 백제로의 전환과 재지세력의 존재양태 [A study on the conversion into Paekche from Mahan and existence aspects of local power in the Miho River Basin]. Hosŏ kogohak 호서고고학 33:70-103.

Peregrine, Peter

1991 Some political aspects of craft specialization. World Archaeology 23(1):1-11.

Rollinson, Hugh R.

2014 Using Geochemical Data: Evaluation, Presentation, Interpretation. New York: Routledge.

Schortman, Edward M., and Patricia A. Urban

2004 Modeling the roles of craft production in ancient political economies. Journal of Archaeological Research 12(2):185-226.

Seoul Taehakkyo Pangmulgwan tong Kogohakkwa 서울大學校 博物館同 考古學科 [SeOUl

National University Museum, Department of Archaeology]

1975 Sŏkch'ŏn-dong chŏksŏk ch'ong palgul chosa pogo 石村洞 積石塚 發掘調査報告 [Stonemounded Tombs at Sŏkch'on-dong, Seoul]. Seoul Taehakkyo kogo illyuhak ch'onggan che yuk-ch'aek 서울大學校 考古人類學叢刊 第六冊 [Archaeological and Anthropological Papers of Seoul National University no. 6]. Seoul: Seoul Taehakkyo Pangmulgwan.

Smith, Michael E.

2004 The archaeology of ancient state economies. Annual Review of Anthropology 33:73-102.

Sŏ HYŎNJu 서현주 [SEO HYUN-JU]

2014 Chŏnnam chiyŏk Mahan cheguk ŭi sahoe sŏnggyŏk kwa Paekche; ch'ult'o yumul ro pon Chŏnnam chiyŏk Mahan cheguk ŭi sahoe sŏnggyŏk -5 6 segi t'ogi rŭl chungsim ŭro 전남지역 마한 제국의 사회 성격과 백제; 출토유물로 본 전남지역 마한제국의 사회 성격 $-5 \sim 6$ 세기 토기를 중심으로 [A study on the character of Mahan society in the Chŏnnam region through excavated artifacts: With a focus on the earthenware from the 5 th and 6th century]. Paekche hakpo 百濟學報 11:71-90.

SŎNG ChŎNGYONG 성정용 [SEONG JEONG YONG]

2012 Chŭngp'yŏng Isŏng Sansŏng ch'ult'o t'ogi yangsang kwa kŭ sŏnggyŏk 증평 이성산성 출토 토기양상과 그 성격 [Aspects and nature of pottery from Chŭngp'yŏng Isŏng Fortress]. Hoš kogohak 호서고고학 27:44-65.

2016 Hosŏ chiyŏk ŭi Mahan kwa Paekche yujŏk chosa sŏnggyŏk 호서지역의 마한과 백제 유적조사 성과 [Results of the 2015 archaeological investigations of the Mahan and Paekche relics in the Hosŏ region]. Paekche hakpo 百濟學報 18:5-33.

Stahl, Ann B., Maria das Dores Cruz, Hector Neff, Michael D. Glascock, Robert J. Speakman, Bretton Giles, and Leith Smith

2008 Ceramic production, consumption and exchange in the Banda Area, Ghana: Insights from compositional analyses. Journal of Anthropological Archaeology 27(3):363-381.

Stark, M. T., R. L. Bishop, and E. Miksa

2000 Ceramic technology and social boundaries: Cultural practices in Kalinga clay selection and use. Journal of Archaeological Method and Theory 7(4):295-331.

TSUCHIDA Junko 土田純子

2013 Ilban nonmun: Mahan, Paekche chiyŏk ch'ult'o ch’wi sayonggi pyŏnch'ŏngo 일반논문: 마한, 백제지역 出土 취사용기 변천고 [Development of cookery tools excavated in Mahan and Paekche areas]. Paekche yon'gu 百濟研究 58:151-181.

Underhill, AnNe P.

2015 What is special about specialization? in Emerging Trends in the Social and Behavioral Sciences (online resource), ed. R. A. Scott and S. M. Kosslyn. Available from Wiley Online Library, doi:10.1002/9781118900772.etrds0384.

Vaughn, Kevin J.

2006 Craft production, exchange, and political power in the Pre-Incaic Andes. Journal of Archaeological Research 14(4):313-344. 
WALSH, RORY

2017 Ceramic Specialization and Exchange in Complex Societies: A Compositional Analysis of Pottery from Mahan and Baekje in Southwestern Korea. Ph.D. diss. University of Oregon.

WynNE-JONES, STEPHANIE

2007 Multiple landscapes and layered meanings: Scale, interaction and process in the development of a Swahili town, in Socialising Complexity: 142-160, ed. Stephanie Wynne-Jones and Sheila Kohring. Oxford: Oxbow Books.

YANG KISǑK 梁起錫 [YANG GI-SEOK]

2013 Chŏnnam chiyŏk Mahan soguk kwa Paekche: Chŏnnam chiyŏk Mahan sahoe wa Paekche 전남지역 미한 소국과 백제: 전남지역 마한사회와 백제 [Mahan and Paekche in South Chŏlla Province]. Paekche hakpo 百濟學報 9:1-21.

Yi, HYUNHAE

2009 The formation and development of the Samhan, in Early Korea 2: The Samhan Period in Korean History: 17-59, ed. Mark E. Byington. Cambridge, MA: Harvard University Press.

Yi NAMSŎK 이남석 [LEE NAM SEOK]

2013 Mahan punmyo wa kŭ myoje ŭi insik 마한분묘와 그 묘제의 인식 [Understanding Mahan's tombs and its burial system]. Mahan Paekche munhwa 마한백제 문화 22:115-143.

YI SŎNBOK 이선복 [Yi SEONBOK], YANG SIŬN 양시은 [YANG SI-Eun], Ch’o KaYŎNG 초가영 [CHO GAYEONG], AND KIM CHUNGYU 김준규 [KIM Jun-KYU]

2013 Sŏkch'ŏn-dong kobun'gun I 석천동 고분군 I [Sǒkch’ŏn-dong Tombs I]. Seoul Taehakkyo Pangmulgwan haksul ch'ongsŏ 서울대학교박물관학술총서 [Seoul National University Museum Academic Series] 19. Seoul: Seoul Taehakkyo Ch'ulp'an Munhwawŏn.

Yi SŏNGJu 이성주 [LEE SUNGJOO]

2013 Ch'olgi sidae Tongbuga che chiyŏk sahoe ŭi kisul hyŏksin kwa sahoe pyŏndong 철기시대 동북아 제 지역사회의 기술혁신과 사회변동 [Technological innovations and social dynamics in the three different regions of the Early Iron Age]. Sŏnsa wa kodae 선사와고대 38:193-226.

2015 P'ungnap T'osŏng t'ogi yumulgun ŭi yŏndae wa Paekche t'ogi Hansŏng yangsik ŭi sŏngnip 풍납토성 토기유물군의 연대와 백제토기 한성양식의 성립 [Dating the ceramic assemblages of Pungnap walled-town and defining the Hansong style]. Honam kogo hakpo 湖南考古學報 49:135-174. 